\title{
Origin and variability of upper tropospheric nitrogen oxides and ozone at northern mid-latitudes
}

\author{
V. Grewe ${ }^{1,2}$, D. Brunner ${ }^{3}$, M. Dameris ${ }^{2}$, J.L. Grenfell ${ }^{1}$, R. Hein ${ }^{2}$ and \\ D. Shindell ${ }^{1}$, J. Staehelin ${ }^{4}$
}

${ }^{1}$ NASA Goddard Institute for Space Studies and Center for Climate Systems Research, Columbia University, New York, USA, ${ }^{2}$ DLR-Institut für Physik der Atmosphäre, Deutsches Zentrum für Luft- und Raumfahrt (DLR), Oberpfaffenhofen, Germany, ${ }^{3}$ Royal Netherlands Meteorological Institute (KNMI), Section of Atmospheric Composition, De

Bilt, The Netherlands, ${ }^{4}$ Institute for Atmospheric Science, Swiss Federal Institute of Technology (ETH), Zürich, Switzerland

Abstract. Measurements of $\mathrm{NO}_{\mathrm{x}}$ and ozone performed during the NOXAR project are compared with results from the coupled chemistry-climate models ECHAM4.L39(DLR)/CHEM and GISS-model. The measurements are based on flights between Europe and the East coast of America and between Europe and the Far East in the latitude range $40^{\circ} \mathrm{N}$ to $65^{\circ} \mathrm{N}$. The comparison concentrates on tropopause altitudes and reveals strong longitudinal variations of seasonal mean $\mathrm{NO}_{x}$ of 200 pptv. Either model reproduced strong variations $3 \mathrm{~km}$ below but not at the tropopause, indicating a strong missing $\mathrm{NO}_{x}$ or $\mathrm{NO}_{y}$ sink over remote areas, e.g. $\mathrm{NO}_{x}$ to $\mathrm{HNO}_{3}$ conversion by $\mathrm{OH}$ from additional $\mathrm{OH}$ sources or $\mathrm{HNO}_{3}$ wash-out. Vertical profiles show maximum $\mathrm{NO}_{x}$ values 2 $3 \mathrm{~km}$ below the tropopause with a strong seasonal cycle. ECHAM4.L39(DLR)/CHEM reproduces a maximum, although located at the tropopause with a less pronounced seasonal cycle, whereas the GISS model reproduces the seasonal cycle but not the profile's shape due to its coarser vertical resolution. A comparison of $\mathrm{NO}_{\lambda}$ frequency distributions reveals that both models are capable of reproducing the observed variability, except that ECHAM4.L39(DLR)/CHEM shows no very high $\mathrm{NO}_{\mathbf{x}}$ mixing ratios. Ozone mean values, vertical profiles and frequency distributions are much better reproduced in either model, indicating that the $\mathrm{NO}_{\mathrm{x}}$ frequency distribution, namely the most frequent $\mathrm{NO}_{\mathrm{x}}$ mixing ratio, is more important for the tropospheric photochemical ozone production than its mean value.

Both models show that among all sources, $\mathrm{NO}_{\mathrm{x}}$ from lightning contributes most to the seasonal cycle of $\mathrm{NO}_{x}$ at tropopause altitudes. The impact of lightning in the upper troposphere on $\mathrm{NO}_{x}$ does not vary strongly with altitude, whereas the impact of surface emissions decreases with altitude. However, the models show significant differences in lightning induced $\mathrm{NO}_{x}$ concentrations, especially in winter, which may be related to the different treatment of the lower stratospheric coupling between dynamics and chemistry.

Keywords: NOXAR, GCM, upper troposphere $\mathrm{NO}_{\mathrm{x}}$ and ozone, Lightning $\mathrm{NO}_{\mathrm{x}}$

$$
\text { Almos plumi trmonoment }
$$




\section{INTRODUCTION}

Global numerical simulations have been widely used in the past years to evaluate the influence of anthropogenic emissions on climate. Tropospheric gas phase chemistry modeling focussed strongly on ozone because of its role as a greenhouse gas. It has a pronounced sensitivity in radiative forcing peaking at the tropopause altitude (Wang and Sze, 1980). In addition, model studies suggest stronger climate sensitivity than well-mixed greenhouse gases (Ponater et al., 1999). Recent results suggest that global tropospheric ozone increase since pre-industrial times lead to a radiative forcing of 0.3 to $0.6 \mathrm{~W} \mathrm{~m}^{-2}$ (WMO, 1999) enhancing significantly the global mean forcing of well-mixed greenhouse gases of 2.25 to $2.5 \mathrm{~W} \mathrm{~m}^{-2}$ (IPCC, 1996). Furthermore, numerical simulations were used to assess the inf rence of the increasing air traffic which, leads to significant $\mathrm{NO}_{x}$-emissions at flight altitude (IPCC, 1999).

The abundance of reactive nitrogen compounds, such as $\mathrm{NO}, \mathrm{NO}_{2}$, and $\mathrm{NO}_{3}\left(=\mathrm{NO}_{x}\right)$, has changed significantly since pre-industrial time (Lelieveld and Thompson, 1999). Major contributors to the concentration of upper troposphere $\mathrm{NO}_{\mathrm{x}}$ are lightning, aviation and $\mathrm{NO}_{\mathrm{x}}$ emissions at the surface, which largely consist of energy consumption, soils, vegetation and biomass burning. Ozone production, and therefore climatic impacts, depend on the $\mathrm{NO}_{x}$ concentration (Fishman and Crutzen, 1979; Fishman et al., 1979). Coupled chemistry-climate models, used to assess climate impacts from $\mathrm{NO}_{\mathrm{x}}$ emissions, need to be able to simulate realistically $\mathrm{NO}_{\mathrm{x}}$ and ozone.

However, the level of confidence of the magnitude of the increase of tropospheric ozone is low (IPCC, 1996), because the knowledge is mainly based on numerical simulations. The physical and chemical processes, which determine global tropospheric ozone concentrations, are very complex. They need to be simplified in global numerical models mainly because of limitations of modern computer facilities. Comparisons of the $\mathrm{NO}_{\mathrm{x}}$-fields at $200 \mathrm{hPa}$ calculated by ten state of the art models show pronounced disagreement with respect to the absolute concentrations and the horizontal variations (Brasseur et al., 1998). The first systematic comparison between the available $\mathrm{NO}_{x}$ measurements with numerical simulations was made by Emmons et al. (1997). However, $\mathrm{NO}_{\mathrm{x}}$ measurements at the tropopause altitude have been rather limited in the past because they were restricted to aircraft campaigns.

The NOXAR (Nitrogen OXides and ozone measurements along Air Routes) measurements now enable an extensive model validation with regard to upper troposphere $\mathrm{NO}_{\mathrm{x}}$ and ozone. These measurements were performed from a passenger aircraft during a one-year period ending in May 1996. The permanently installed measurement system recorded chemical and meteorological data on 270 return flights between Europe and destinations in the United States of America and Far East, and is therefore one of the largest data sets for upper troposphere NO (Brunner, 1998).

The present investigation has two primary aims: First, an extensive comparison of NOXAR measurements with the climate-chemistry models ECHAM4.L39(DLR)/CHEM and the GISS model will give a better understanding of upper troposphere dynamical and chemical processes. Second, sensitivity studies with both models provide an interpretation of the NOXAR measurements in terms of the origin of upper troposphere $\mathrm{NO}_{x}$ and ozone.

The ECHAM4.L39(DLR)/CHEM and the GISS model have similar concepts for the description of the meteorology which is described by the physical part of the model. It provides detailed 
information for the chemistry module about the state of the atmosphere, like cloud cover and structure, precipitation, temperature, and radiation, necessary for the calculation of photolysis and reaction rates, $\mathrm{NO}_{x}$ sinks (e.g. wet deposition) and sources (e.g. lightning). This is different to many chemical transport models, which use prescribed meteorological fields as provided by e.g. ECMWF and climatological values for cloud processes. The tropospheric chemical schemes are quite similar in either model. Differences between the models, which are important in the context of this study, include vertical resolution, different lightning parameterizations and the treatment of the lower stratosphere. ECHAM4.L39(DLR)/CHEM includes a description of the lower stratosphere dynamics and chemistry, which is not explicitly treated in the GISS model but based on prescribed fixed fields (see next section). In this comparison very similar $\mathrm{NO}_{\mathrm{x}}$ emission strengths are used.

\section{DATA-SET AND MODELS}

\subsection{NOXAR measurements}

The NOXAR measurement system was permanently installed on a Swissair B-747 airliner. The instrumentation package consisted of commercial analyzers for the measurements of NO, $\left(\mathrm{NO}_{2}+\mathrm{NO}_{3}\right.$ ) (chemiluminescence) and ozone (UV-Photometer). Calibrations were automatically initiated in regular time steps. Detection limits of 23, 45, and $500 \mathrm{pptv}$ were achieved for 2minute mean concentrations of $\mathrm{NO},\left(\mathrm{NO}_{2}+\mathrm{NO}_{3}\right)$, and ozone, respectively. The accuracies are 8 , 11 and $6 \%$, respectively. $\left(\mathrm{NO}_{2}+\mathrm{NO}_{3}\right)$ concentrations were calculated from daytime $\mathrm{NO}$ and $\mathrm{O}_{3}$ measurements assuming a photostationary steady state. Measured values were only used for nighttime flights when available. Due to instrumental problems, no $\left(\mathrm{NO}_{2}+\mathrm{NO}_{3}\right)$ was measured between May and November 1995. Average daytime $\mathrm{NO}_{x}$ concentrations based on measured and on calculated $\left(\mathrm{NO}_{2}+\mathrm{NO}_{3}\right)$ agreed within $11 \%$. Preference was given to the calculated values because of the rather low precision of the $\left(\mathrm{NO}_{2}+\mathrm{NO}_{3}\right)$ measurement. Details are given in Brunner (1998). Data, which were identified to be influenced by young aircraft plumes were excluded.

Meteorological parameters were recorded from the aircraft data system. The NOXAR measurements cover mid-latitudinal flight tracks, mainly between $40^{\circ} \mathrm{N}$ and $65^{\circ} \mathrm{N}$ and from Eastern parts of North America to Central Europe and to China (Figure 1). Dias-Lalcaca et al. (1998) and Brunner (1998) give detailed descriptions and include also more southern flights to Bombay and Hong Kong. On those flights, the airplanes were usually flying several kilometers below the tropopause so that they are not included here.

\section{Figure 1: Area of measurements}

\subsection{ECHAM4.L39(DLR)/CHEM model}

The dynamical part of the coupled climate-chemistry model ECHAM4.L39(DLR)/CHEM is the ECHAM4.L39(DLR) model. It represents an advancement of the operationally used general circulation model ECHAM4 (Roeckner et al., 1996) regarding the vertical resolution, which has been increased from 19 to 39 levels from the surface to the top layer, centered at $10 \mathrm{hPa}(30 \mathrm{~km})$ (Land, 1999; Land et al., 1999). This model version has been designed especially for upper troposphere and lower stratosphere processes. It includes state of the art parameterizations of radiation, cloud, surface and soil processes, gravity wave drag, vertical diffusion, convection, and semi-Lagrangian transport for water vapor, cloud water and chemical species. The model 
generates its own climate, which depends only on prescribed sea surface temperatures (Gates, 1992) and the atmospheric $\mathrm{CO}_{2}$ concentration for 1990 and either interactively calculated (online chemistry coupling) or prescribed (offline chemistry coupling) concentrations of the radiatively active gases $\mathrm{H}_{2} \mathrm{O}, \mathrm{O}_{3}, \mathrm{CH}_{4}, \mathrm{~N}_{2} \mathrm{O}$, and CFCs. A detailed validation of the ECHAM4.L39(DLR) model is given in Land (1999).

The chemistry module CHEM (Steil et al., 1998) has been coupled to ECHAM4.L39(DLR) (Hein et al., 2000). It includes stratospheric heterogeneous and homogeneous ozone chemistry and tropospheric $\mathrm{NO}_{x}-\mathrm{CH}_{4}-\mathrm{CO}-\mathrm{OH}-\mathrm{O}_{3}$-chemistry with 107 photochemical reactions and 37 species. Surface emissions of $\mathrm{NO}_{\mathbf{x}}$ due to industry, soils, and biomass burning are based on Benkovitz et al. (1996), Yienger and Levy (1995) and Hao et al. (1990), respectively. Aircraft $\mathrm{NO}_{\mathrm{x}}$ emissions are based on the DLR2 data set (Schmitt and Brunner, 1998), NO $\mathrm{N}_{\mathrm{x}}$ emissions by lightning are calculated interactively according to Price and Rind (1994) (see Table 1).

\begin{tabular}{|c|c|c|c|c|c|c|c|}
\hline \multirow[b]{2}{*}{ Model } & \multirow{2}{*}{$\begin{array}{c}\text { Grid } \\
\text { [layer] } \\
\text { [lat } \times \\
\text { lon] }\end{array}$} & \multirow[b]{2}{*}{$\begin{array}{c}\text { Top } \\
\text { layer } \\
\text { (center) }\end{array}$} & \multicolumn{3}{|c|}{$\begin{array}{l}\mathrm{NO}_{\mathrm{x}} \text { emissions } \\
{\left[\mathrm{TgN} \mathrm{a}^{-1}\right]}\end{array}$} & \multirow{2}{*}{$\begin{array}{c}\text { Upper } \\
\text { boundary } \\
\text { condition } \\
\text { for } \\
\text { chemistry }\end{array}$} & \multirow{2}{*}{$\begin{array}{l}\text { Characteristics } \\
\text { which differ in } \\
\text { the models }\end{array}$} \\
\hline & & & $\underset{E}{\mathscr{E}}$ & 胥. & 点. & & \\
\hline $\begin{array}{l}\text { ECHAM4. } \\
\text { L39(DLR) } \\
\text { /CHEM }\end{array}$ & $\begin{array}{c}39 \\
3.75^{\circ} \times \\
3.75^{\circ}\end{array}$ & $10 \mathrm{hPa}$ & 33.1 & 0.56 & 5.0 & $\begin{array}{l}\mathrm{Cl}_{\mathrm{y}}, \mathrm{NO}_{\mathrm{y}} \text { at } \\
10 \mathrm{hPa}\end{array}$ & $\begin{array}{l}\text { U.Tropo-L. } \\
\text { Strat-Dynamic- } \\
\text { chem.Coupling }\end{array}$ \\
\hline GISS & $\begin{array}{c}9 \\
4^{\circ} \times 5^{\circ}\end{array}$ & $40 \mathrm{hPa}$ & 31.4 & 0.51 & 4.7 & $\begin{array}{l}\mathrm{NO}_{y}, \mathrm{O}_{3}, \\
\mathrm{NO}_{\mathrm{x}}: \mathrm{HNO}_{3} \text {, } \\
\text { at Level } 8\end{array}$ & $\begin{array}{l}\mathrm{N}_{2} \mathrm{O}_{5} / \text { sulfate } \\
\text { aerosol hetero- } \\
\text { geneous react. }\end{array}$ \\
\hline
\end{tabular}

Table 1: Brief comparison of the coupled chemistry-climate models ECHAM4.L39(DLR)/CHEM and GISS.

\subsection{GISS model}

The GISS II' ('two prime') GCM (Hansen et al., 1997a) was developed from the GISS GCM version II which is described fully by Hanson et al. (1983). GISS II' is a gridpoint model having a 4x5 degrees horizontal resolution and 9 sigma-pressure hybrid levels in the vertical. Climatological, monthly sea surface temperature data based on the Atmospheric Modeling Intercomparison Project (AMIP) 1979-1993 and ocean ice coverage are incorporated. The radiation scheme determines radiative heating in the short- and longwave spectral regions for all important radiatively active species in the troposphere and stratosphere (Hansen et al., 1983). The II' version employs several improvements over model II, including new convection (Del Genio and Yao, 1992), prognostic cloud (Del Genio et al. 1996), planetary boundary layer (Hartke and Rind, 1997) and ground hydrology (Rosenzweig and Abramopoulos, 1997) treatments, as well as improvements to the albedo calculation over land (Rossow and Zhang, 
1995), ocean (Gordon and Wang, 1994) and sea ice (Hansen et al., 1997b). Tracers are advected using the quadratic upstream method (Rind and Lerner, 1996), which produces little numerical noise and realistically maintains strong tracer gradients. A detailed description can be found in Rind and Lerner (1996).

The GISS model includes 10 chemical tracers $\left(\mathrm{O}_{x}, \mathrm{NO}_{x}, \mathrm{~N}_{2} \mathrm{O}_{5}, \mathrm{HNO}_{3}, \mathrm{H}_{2} \mathrm{O}_{2}, \mathrm{CH}_{3} \mathrm{OOH}, \mathrm{HCHO}\right.$, $\mathrm{HO}_{2} \mathrm{NO}_{2}, \mathrm{CO}$ and $\mathrm{H}_{2} \mathrm{O}$ ) using the 'family' approach, where appropriate with 52 reactions for 24 species (DeMore et al., 1997). Peroxyacetyl nitrate (PAN) and explicit non-methane hydrocarbon (NMHC) chemistry is omitted. The 'FASTJ' photolysis scheme, after validation with results from the Photochemical Model Intercomparison (PhotoComp, Olson et al., 1997), is employed. $\mathrm{N}_{2} \mathrm{O}_{5}$ hydrolysis on sulfate aerosol is calculated according to Dentener and Crutzen (1993) using monthly mean modeled sulfate surface area taken from Koch et al. (1999). Wet and dry depositions are adapted from Wang et al. (1998). The lightning parameterization generates $\mathrm{NO}_{\mathrm{x}}$ interactively with the convection scheme (Price et al., 1997). Chemical emissions are prescribed as monthly-mean values and include $\mathrm{CO}$ (biomass, equivalent isoprene and industrial) and $\mathrm{NO}_{\mathrm{x}}$ (industrial, biomass burning, soils, and aircraft). The GISS climate-chemistry model is documented extensively and validated against observational data in Shindell et al. (2000).

\subsection{Experimental set-up}

For the comparison of the model results with the NOXAR measurements (sections 3 to 5) two numerical simulations performed with the ECHAM4.L39(DLR)/CHEM and one performed with the GISS model were taken into account (Table 2). The ECHAM4.L39(DLR)/CHEM model was run in two modes: on-line and off-line. In the on-line mode feedbacks from the chemistry module to radiation via changes in ozone, water vapor, methane, nitrous dioxide, and CFCs are allowed, whereas in the off-line mode those species are prescribed for the radiation module with climatological values. Two and one year spin-up times are employed for the ECHAM4.L39(DLR)/CHEM and the GISS model, respectively. Since the coupling of the upper troposphere and lower stratosphere is included in the ECHAM4.L39(DLR)/CHEM model, whereas the GISS model has there its upper boundary, and since the chemical lifetime of $\mathrm{NO}_{\mathrm{x}}$ is larger in the lower stratosphere than in the upper troposphere, a longer spin-up time has to be taken into account for ECHAM4.L39(DLR)/CHEM. After the spin-up time inter-annual variability occurs, but no clear trend is visible.

In addition to the control runs shown in Table 2, perturbation simulations were performed with both models in order to estimate the impact of various $\mathrm{NO}_{\mathrm{x}}$ sources on the $\mathrm{NO}_{\mathrm{x}}$ and ozone distribution in the upper troposphere measured during the NOXAR project (section 6). For each $\mathrm{NO}_{\mathrm{x}}$ source (aircraft, lightning, surface) simulations have been performed with both models, which neglect each source in turn. For the GISS model the impact of the upper boundary has also been investigated by setting the $\mathrm{NO}_{\mathrm{x}}$ upper boundary equal to zero. The ECHAM4.L39(DLR)/CHEM model was run for these simulations in the off-line mode and the GISS model in the on-line mode. Five and two years simulations were performed including a spin-up time of two and one years for the ECHAM4.L39(DLR)/CHEM and the GISS model, respectively. 


\begin{tabular}{|l|l|c|c|}
\hline \multicolumn{1}{|c|}{ Experiment } & \multicolumn{1}{|c|}{ Model } & Sim. Length & Mode \\
\hline E4C-on & ECHAM4.L39(DLR)/CHEM & $2 y+5 y$ & On-line \\
\hline E4C-off & ECHAM4.L39(DLR)/CHEM & $2 y+5 y$ & Off-line \\
\hline GISS-on & GISS & $1 y+9 y$ & On-line \\
\hline
\end{tabular}

Table 2: Experimental set-up for the control simulations for the ECHAM4.L39(DLR)/CHEM and the GISS models.

\subsection{Model differences}

Regarding the dynamical part of the GISS and the ECHAM4.L39(DLR)/CHEM model, main differences occur in the vertical resolution of 9 and 39 layers and the tracer transport schemes, quadratic upstream and semi-Lagrangian method, respectively. Numerical diffusion caused by the coarser resolution of the GISS model may be compensated by the transport scheme, which maintains strong tracer gradients.

The chemical schemes and $\mathrm{NO}_{\mathrm{x}}$ sources and sinks of either model are quite similar. However, the GISS model includes an additional $\mathrm{NO}_{x}$ sink $\left(\mathrm{N}_{2} \mathrm{O}_{5}\right.$ hydrolysis on sulfate aerosol) and takes cloud to cloud and cloud to ground flashes into account and applies a $\mathrm{C}$-shape $\mathrm{NO}_{\mathrm{x}}$ emission profile, whereas ECHAM4.L39(DLR)/CHEM applies a uniform mixing for cloud to ground flashes. Although the total amount of $\mathrm{NO}_{\mathrm{x}}$ released into the atmosphere is similar in both models, the GISS model releases significantly more in the upper troposphere due to the differences in the parameterization.

An important difference is also the coupling of dynamical-chemical processes in the upper troposphere and lower stratosphere. The GISS model has an upper boundary for $\mathrm{NO}_{\mathrm{x}}$ and $\mathrm{O}_{3}$ at $110 \mathrm{hPa}$, which excludes transport of $\mathrm{NO}_{\mathrm{x}}$ from the tropical upper troposphere to the lower midlatitude stratosphere. The ECHAM4.L39(DLR)/CHEM includes stratospheric chemistry and accounts for those processes. However, this difference may only be of minor importance for the control experiments, since those processes are implicitly included in the boundary condition, but they definitely affect the sensitivity tests.

The GISS model includes a variety of online diagnostics, like budget calculations, wave analysis, etc. This enables a more detailed analysis compared to the ECHAM4.L39(DLR)/CHEM model.

\subsection{Methodology: Tropopause determination}

The tropopause defies a sharp transition from the troposphere to the stratosphere, where ozone strongly increases. To avoid systematic differences in the comparison between model and observational data, the comparison of NOXAR measurements with model data was performed for the tropopause region. This region represents air masses at the tropopause $\pm 25 \mathrm{hPa}$ for the measurements and the ECHAM4.L39(DLR)/CHEM model data and the $7^{\text {th }}$ level of the GISS 
model ( $200 \mathrm{hPa}$ ), where the GISS model has its temperature minimum regarding mean vertical profiles. The height of the tropopause and its pressure were calculated for every measurement and model time step. Data from the European Centre for Medium-Range Weather Forecasts (ECMWF) were used to calculate height and pressure of the dynamic defined tropopause with a constant value of the potential vorticity (2 PV-Units) and to calculate the distance from the measurements to the tropopause. The height and pressure of the thermal defined tropopause were calculated for ECHAM4.L39(DLR)/CHEM model data. The use of two different approaches to estimate the height of the tropopause does not limit the results since the thermal defined tropopause can be well represented by a constant value of potential vorticity in the region of the measurements (Grewe and Dameris, 1996).

\section{LONGITUDINAL VARIATIONS}

Figure 2 shows the variability of $\mathrm{NO}_{x}$ mixing ratios along the flight tracks between the eastern part of the United States of America and China. In all seasons, large values are observed over America including a seasonal cycle with $150 \mathrm{pptv}$ in winter and $350 \mathrm{pptv}$ in summer. Minimum values were measured over the eastern part of the North Atlantic, varying between $100 \mathrm{pptv}$ and $150 \mathrm{pptv}$ in winter and summer, respectively. Over Eurasia enhanced values were seen over Central Europe $\left(10^{\circ} \mathrm{E}\right.$ to $\left.15^{\circ} \mathrm{E}\right)$ in every season and also over parts of Asia, especially in summer, where $\mathrm{NO}_{x}$ exceeds $350 \mathrm{pptv}$. This means that a large longitudinal variability is observed with an amplitude of $100 \mathrm{pptv}$ in winter and $200 \mathrm{pptv}$ in summer.

\section{Figure 2: Longitudinal variations of $\mathrm{NO}_{\mathrm{x}}$}

Both models, the ECHAM4.L39(DLR)/CHEM (on- and off-line version) and the GISS model, show some longitudinal variation (Figure 2, dotted and solid thin lines), but do not reproduce the observed magnitude. ECHAM4.L39(DLR)/CHEM simulates enhanced $\mathrm{NO}_{\mathrm{x}}$ volume mixing ratios over America and Europe with an amplitude of $30 \mathrm{pptv}$ in winter and $60 \mathrm{pptv}$ in summer. But it misses totally the enhanced Siberian summertime values (see below). Generally, mean values are too low especially over the continents by up to $200 \mathrm{pptv}$, thus the land-ocean contrast is less pronounced. In contrast, the GISS model has a zonal uniform $\mathrm{NO}_{\mathrm{x}}$ distribution at mid latitudes in all seasons with a strong seasonal cycle. The inter-annual variability is much larger in the GISS than in the ECHAM4.L39(DLR)/CHEM model.

The discrepancies, revealed by the comparison, can be restraint to two possible causes:

(1) The upper tropospheric NO ${ }_{x}$ lifetime is too long, i.e. NO ${ }_{x}$ sinks are too weak or even missing, especially over the North Atlantic, where a minimum in the observed $\mathrm{NO}_{\mathrm{x}}$ mixing ratios occurs in all seasons. The inclusion of PAN-chemistry in the models would decrease even further the land-sea contrast in $\mathrm{NO}_{\mathrm{x}}$ as it would be converted into PAN near the sources, i.e. over the continents, and produced over remote areas, i.e. the sea. Instead, the inclusion of an additional $\mathrm{OH}$ source, like acetone, which has similar source regions as $\mathrm{NO}_{\mathrm{x}}$, but a longer lifetime, would provide a source of $\mathrm{OH}$ in remote areas (Arnold et al., 1997). This leads to a $\mathrm{NO}_{x}$ sink over the North Atlantic due to the reaction $\mathrm{NO}_{2}+\mathrm{OH}+\mathrm{M} \rightarrow \mathrm{HNO}_{3}+\mathrm{M}$. 
(2) $\mathrm{NO}_{x}$ production from $\mathrm{HNO}_{3}$ photolysis may be too strong, which implies either to large mixing or again a to small total sink of $\mathrm{NO}_{\mathrm{y}}$ at tropopause altitude. The tropopause region is a sharp transition between the tropospheric circulation and the stratospheric circulation, which is dominated by zonal structures. At $300 \mathrm{hPa}$, i.e. approximately $3 \mathrm{~km}$ below the tropopause, both models show strong latitudinal variations in $\mathrm{NO}_{\mathrm{x}}$ of 35 to $150 \mathrm{pptv}$ and 200 to $400 \mathrm{pptv}$ in the ECHAM4.L39(DLR)/CHEM and GISS model, respectively. The horizontal structures of $\mathrm{NO}_{y}$ are similar to those of $\mathrm{NO}_{\mathrm{x}}$ at each altitude for either model. Both models show strong changes of the simulated patterns of $\mathrm{NO}_{\mathrm{x}}$ and $\mathrm{NO}_{\mathrm{y}}$ from 300 to $200 \mathrm{hPa}$, indicating changes of dynamical or chemical processes, in contrast to observations. At $200 \mathrm{hPa}$, both models overestimate the mean zonal wind by 5 to $10 \mathrm{~ms}^{-1}$ and show to low transient wave energy, which accounts for horizontal patterns, in mid-latitudes at tropopause levels (Land, 1999). This leads to a more intense mixing of $\mathrm{NO}_{x}$ and $\mathrm{NO}_{y}$ at tropopause altitudes. However, the deviations from observations are not large enough to leve: off $\mathrm{NO}_{\mathrm{x}}$ and $\mathrm{NO}_{\mathrm{y}}$ variations. Therefore, this leads again to a missing sink. A sink of $\mathrm{NO}_{y}$ can only be wash-out of $\mathrm{HNO}_{3}$, suggesting that modeled wash-out processes are underestimated in both models at mid-latitude tropopause region. For mid-latitudes observed vertical profiles of precipitation and cloud water are not available. First results of observations in the tropics (Tropical Rainfall Measuring Mission, TRMM) suggest that ocean storms produce precipitation water at higher altitudes compared to land storms (Del Genio, personal communication, 2000). Since the GISS model simulates precipitation water at lower altitudes and without any land-sea contrast, one could speculate that this also occurs at mid-latitudes. This would lead to an underestimation of the washout of $\mathrm{HNO}_{3}$ especially over the North Atlantic.

A comparison of the zonal mean chemical $\mathrm{NO}_{\mathrm{x}}$ loss rate at 200 and $300 \mathrm{hPa}$ in the latitude band $40^{\circ} \mathrm{N}$ to $60^{\circ} \mathrm{N}$ in July reveals for the GISS model large differences of $1.4 \times 10^{7} \mathrm{~s}^{-1}$ and $22 \times 10^{7} \mathrm{~s}^{-1}$, respectively (see also Figure 4). This leads to a change of the process, which controls $\mathrm{NO}_{\mathrm{x}}$ in the GISS model: chemistry at $300 \mathrm{hPa}$ and dynamics at $200 \mathrm{hPa}$. This supports reason (1) that the $\mathrm{NO}_{\mathrm{x}}$ sink is underestimated at $200 \mathrm{hPa}$. However, it does not exclude (2).

The upper troposphere source for $\mathrm{NO}_{x}$ in the ECHAM4.L39(DLR)/CHEM seems to be underestimated, whereas in the GISS model this source is overestimated in spring, summer, and fall. Thus ECHAM4.L39(DLR)/CHEM shows mean $\mathrm{NO}_{\mathrm{x}}$ values, which are typically North Atlantic, i.e. around 100 pptv with a small seasonal cycle, whereas the GISS model reflects typically land situations, such as over the eastern part of the U.S.A. or Europe, with higher values and a strong seasonal cycle.

Although ECHAM4.L39(DLR)/CHEM shows enhanced $\mathrm{NO}_{\mathrm{x}}$ values over America and Europe in summer, the model fails to simulate enhanced values over Siberia. Measurements of lightning events performed with the Optical Transient Detector (OTD, Christian et al., 1996) give evidence for strong lightning in that area in summer, which locally has the same order of magnitude as the maximum values observed in tropical areas. Since the model simulates much less lightning there (not shown), a significant $\mathrm{NO}_{\mathrm{x}}$ source is missing in that area, which is probably the main reason for that discrepancy.

\section{VERTICAL DISTRIBUTION}

Figure 3 shows the mean vertical $\mathrm{NO}_{\mathrm{x}}$ profiles for each season. Observed maximum values are located $2-3 \mathrm{~km}$ below the tropopause. A clear seasonal cycle is observed with values approximately twice as high in spring and summer than in fall and winter. 


\section{Figure 3: Vertical Profile of $\mathrm{NO}_{\mathbf{x}}$}

As already stated above, the ECHAM4.L39(DLR)/CHEM model shows too low $\mathrm{NO}_{x}$ values for all seasons at the tropopause altitude. However, it is able to simulate a local maximum at the tropopause, i.e. 2 to $3 \mathrm{~km}$ higher than observed. The measured seasonal cycle with low values (75 pptv) in winter and high values (150 pptv) in summer is quite well reproduced regarding the summer to winter ratio: it shows twice as high values in summer than in winter. Due to the coarse vertical resolution, the GISS model only shows a local maximum at the tropopause in July, but simulates a reasonable seasonal cycle.

The more detailed diagnostics of the GISS model enables a closer look at the discrepancy of the location of the summertime $\mathrm{NO}_{x}$ maximum. At $200 \mathrm{hPa}$ and in the latitude range $40^{\circ} \mathrm{N}$ to $60^{\circ} \mathrm{N}$ and $175 \mathrm{hPa}$ to $260 \mathrm{hPa}$, lightning is the dominant $\mathrm{NO}_{\mathrm{x}}$ sulirce $\left(10.5 \mathrm{~kg} \mathrm{~s}^{-1}\right)$ and meridional and vertical transport the dominant $\mathrm{NO}_{\mathrm{x}}$ sink $\left(9.7 \mathrm{~kg} \mathrm{~s}^{-1}\right.$ ) (Figure 4). Below, at $260 \mathrm{hPa}$ to $400 \mathrm{hPa}$, convection $\left(14 \mathrm{~kg} \mathrm{~s}^{-1}\right)$ is a more important source for $\mathrm{NO}_{\mathrm{x}}$ than lightning $\left(5.8 \mathrm{~kg} \mathrm{~s}^{-1}\right)$ and transport $\left(2.6 \mathrm{~kg} \mathrm{~s}^{-1}\right)$. Chemistry is the only important sink $\left(18 \mathrm{~kg} \mathrm{~s}^{-1}\right)$. Although the total $\mathrm{NO}_{\mathrm{x}}$ source is smaller at $200 \mathrm{hPa}$ than at $300 \mathrm{hPa}$ the $\mathrm{NO}_{\mathrm{x}}$ mixing ratios at $200 \mathrm{hPa}$ exceed those at $300 \mathrm{hPa}$ because of the larger $\mathrm{NO}_{\mathrm{x}}$ residence time at $200 \mathrm{hPa}$, which in term depend on the sink terms. In section 3 we suggested that a strong $\mathrm{NO}_{x}$ sink is missing at tropopause levels, e.g. $200 \mathrm{hPa}$. This would imply a decrease of the location of $\mathrm{NO}_{x}$ maximum, supporting the findings in section 3 .

\section{Figure 4: $\mathrm{NO}_{\mathrm{x}}$ Budgets}

Ozone profiles are viewed in Figure Figure 5. Measurements show troposphere values of 40 to $50 \mathrm{ppbv}$ in winter and 60 to $70 \mathrm{ppbv}$ in summer and a sharp increase at the tropopause for all seasons. Although the models obviously have problems in representing the longitudinal $\mathrm{NO}_{x}$ variations, the vertical ozone distribution agrees very well with the observations. Even the sharp gradient at the tropopause is well reproduced by the ECHAM4.L39(DLR)/CHEM model in winter and spring and is only slightly smeared in other seasons. Despite its coarser vertical resolution, the GISS model also simulates a sharp gradient at the tropopause.

Figure 5: $\mathrm{O}_{3}$ Profiles

\section{TEMPORAL VARIABILITY}

The frequency distribution of $\mathrm{NO}_{x}$ at tropopause levels, derived with the NOXAR measurements (Figure 6) shows broad distributions with peak values between 65 and 85 pptv. NO $\mathrm{x}_{\mathrm{x}}$ mixing ratios of less than 50 pptv occur clearly less often in summer than in other seasons. And instead, high $\mathrm{NO}_{\mathrm{x}}$ mixing ratios of more than $200 \mathrm{pptv}$ occur more often in summer. ECHAM4.L39(DLR)/CHEM (on-line version) simulates the most frequent $N_{x}$ mixing ratios between 40 and 60 pptv and the GISS model in the range of 40 pptv to 110 pptv. Thus, the most frequent $\mathrm{NO}_{\mathrm{x}}$ mixing ratios are slightly too low and too confined in the ECHAM4.L39(DLR)/CHEM model and too low in winter and too high in summer in the GISS model.

The comparison indicates that the $\mathrm{NO}_{\mathrm{x}}$ variability is quite well simulated by both models with two exceptions. (1) The main differences between measurements and ECHAM4.L39(DLR)/CHEM data are the underestimation of high (more than 125 pptv) NO 
mixing ratios. (2) The main differences between measurements and the GISS model is its too strong seasonal cycle with too low values in winter and too high values in summer.

Thus the comparison of the frequency distributions explains quite well the differences in the mean values shown in Figure 2. Mean modeled $\mathrm{NO}_{\mathrm{x}}$ mixing ratios are too low in ECHAM4.L39(DLR)/CHEM, not only because of a systematic shift in the frequency distribution, but mainly due to a lack of the occurrence of high values of more than $100 \mathrm{pptv}$ in winter and 150 pptv in summer. This means that large-scale $\mathrm{NO}_{\mathrm{x}}$ plumes with concentration increases of typically $300 \mathrm{pptv}$ and up to $5 \mathrm{ppbv}$ as described in Brunner et al. (1998) are not observed in the model. However, it does not explain the land-sea contrast viewed in Figure 2, since the measured frequency distributions at North Atlantic sites still show occurrences of air masses with high $\mathrm{NO}_{\mathrm{x}}$ content, although less frequent than over land (not shown). The GISS model shows a shift of the most frequent occurrence of $\mathrm{NO}_{\mathrm{x}}$ mixing ratios to higher values i) summer (solid line). This leads to an overestimate of the $\mathrm{NO}_{\mathrm{x}}$ shown in Figure 2.

The ozone production depends non-linear on the $\mathrm{NO}_{\mathrm{x}}$ concentration. Therefore a realistic simulation of the frequency distribution, namely the most frequent $\mathrm{NO}_{x}$ mixing ratio, is more important for a correct modeling of the total ozone production than mean $N_{x}$ values. This is indicated by the model results: Most frequent $\mathrm{NO}_{\mathbf{x}}$ mixing ratios (Figure 6) are simulated fairly well and also ozone mixing ratios (Figure 5), but not the mean $\mathrm{NO}_{\mathrm{x}}$ values (Figure 2).

\section{Figure 6: Density function $\mathrm{NO}_{x} / \mathrm{O}_{3}$}

The density function of measured ozone at tropopause levels (Figure 6) shows the most frequent occurrences at around $50 \mathrm{ppbv}$ in winter and autumn and at higher values ( $75 \mathrm{ppbv}$ ) in summer and spring. Also the variability is significantly increased in spring and summer. Figure 6 shows a systematic shift of the frequency distribution to higher ozone values in the ECHAM4.L39(DLR)/CHEM model. This may not be over-interpreted, since this is related to the location of the tropopause, which is a sub-grid parameterization. As shown in Figure 5, ozone has a sharp gradient at the tropopause in the measurements as well as in the modeled data. A vertical shift of the tropopause by some hundred meters will result in dramatic changes of the ozone values. Comparison of the width of the density functions yields a good agreement with lower variability in autumn and winter and higher in spring and summer for the ECHAM4.L39(DLR)/CHEM model. The GISS model shows much broader distributions and only small variations between the seasons. That means that the GISS model shows a large seasonal cycle for $\mathrm{NO}_{\mathrm{x}}$ but not for ozone and the ECHAM4.L39(DLR)/CHEM model for ozone but not $\mathrm{NO}_{\mathrm{x}}$.

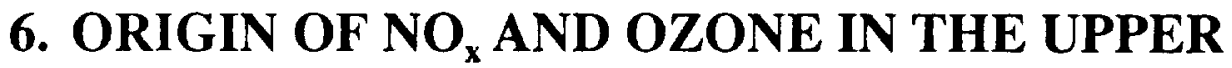 TROPOSPHERE}

To determine the origin of upper troposphere $\mathrm{NO}_{x}$ and ozone, several sensitivity simulations were performed for both models. In each simulation one $\mathrm{NO}_{x}$ source (lightning, aircraft or surface) was excluded. For the GISS model an additional simulation with an upper boundary condition for $\mathrm{NO}_{\mathrm{x}}$ (equal to zero) was done. The simulation lengths are 2 and 5 years including 1 and 2 years spin-up for the GISS and the ECHAM4.L39(DLR)/CHEM models, respectively. Results are summarized in Table 3 and Table 4 for the mid-latitude Northern Hemisphere upper troposphere and they are compared to other model studies. Lightning (5\% to $35 \%$ ) and surface 
$\mathrm{NO}_{\mathrm{x}}$ sources $\left(9 \%\right.$ to $30 \%$ ) contribute with a similar amount to the upper tropospheric $\mathrm{NO}_{\mathrm{x}}$ in winter and are doubled in summer. The contribution due to aircraft emissions shows a large uncertainty among the studies, $11 \%$ to $60 \%$ in winter and half these values in summer. The stratospheric impact is less then $30 \%$ in winter and less than $20 \%$ in summer for all models except the GISS model.

This shows that in winter the low vertical mass exchange by large-scale ascent and convection diminish the importance of surface as well as of lightning $\mathrm{NO}_{\mathrm{x}}$ emissions and increases the importance of aircraft emissions. In the GISS-model, the importance of the stratosphere is quite large, $60 \%$ in winter and $34 \%$ in summer. Figure 4 shows that the downward transport of stratospheric $\mathrm{NO}_{\mathrm{x}}$ is the dominant source for the upper troposphere $\mathrm{NO}_{\mathrm{x}}$ in the GISS model in January, whereas it is only a minor contributor in July. Other model studies (Krauss et al., 1996; Köhler et al., 1997; Brasseur et al., 1998) s rowed a much reduced stratospheric impact of $2 \%$ to $30 \%$ and $5 \%$ to $25 \%$ in January and July, respectively, which suggests that results from the GISS model are influenced by the upper boundary. Consequently, the impact of other $\mathrm{NO}_{\mathrm{x}}$ sources is underestimated, so that the GISS model lies at the lower side of the estimated contributions of the surface and aircraft $\mathrm{NO}_{\mathrm{x}}$ source for January.

The large uncertainties of the importance of lightning for the upper troposphere $\mathrm{NO}_{\mathrm{x}}$ burden, revealed in the comparison, can be attributed to the parameterization of the lightning $\mathrm{NO}_{\mathrm{x}}$ source. Although the total amount of lightning produced $\mathrm{NO}_{x}$ is similar in each model simulation (5 and 4.7 $\mathrm{TgN} \mathrm{a}^{-1}$ ), the vertical distribution is not. In the GISS model vertical profiles derived from measurements (Pickering et al., 1998) are applied, leading to much higher emissions in the upper troposphere than below. Other model studies distributed the $\mathrm{NO}_{\mathrm{x}}$ emitted per lightning flash uniformly with height. The effect is clearly seen, as the GISS model shows a much higher impact of lightning in the upper troposphere in summer than other model studies. Applying C-shape lightning emission profiles (Pickering et al. 1998) to the ECHAM4.L39(DLR)/CHEM model shows a $70 \%$ to $75 \%$ contribution of the lightning $\mathrm{NO}_{x}$ source to the upper troposphere mid latitude $\mathrm{NO}_{\mathrm{x}}$ burden, confirming these findings.

\begin{tabular}{|l|c|c|c|c|c|c|c|}
\hline January & E4C & GISS & Kr96 & Kö97 & Br98 & Br98* $^{*}$ & Total \\
\hline Lightning & 18 & 18 & $<10$ & 5 & $30-35$ & & $5-35$ \\
\hline Surface & 25 & 9 & 30 & 25 & 10 & & $9-30$ \\
\hline Aircraft & 51 & 11 & 60 & 57 & 15 & $13-26$ & $11-60$ \\
\hline Stratosphere & - & 60 & $<10$ & 2 & $15-30$ & & $2-60$ \\
\hline
\end{tabular}

Table 3: Contribution [in \% relative to the control simulation] of various $\mathrm{NO}_{\mathrm{x}}$ sources to the atmospheric $\mathrm{NO}_{x}$ content at tropopause levels and in the area of the NOXAR measurements (see Figure 1) for the ECHAM4.L39(DLR)/CHEM and GISS model. Results of the model studies Krauss et al. (1996) (Kr96), Köhler et al. (1997) (Kö97) and Brasseur et al. (1998) (Br98) are added for the northern hemisphere mid latitudes $\left(30^{\circ} \mathrm{N}\right.$ to $\left.60^{\circ} \mathrm{N}\right)$ at $200 \mathrm{hPa}$. Brasseur et al. 
(1998) concentrated on the effect of aircraft emissions and presented results from an intercomparison of 4 models (Br $\left.98^{*}\right)$.

\begin{tabular}{|l|c|c|c|c|c|c|c|}
\hline July & E4C & GISS & Kr96 & Kö97 & Br98 & Br98* & Total \\
\hline Lightning & 36 & 56 & 20 & 16 & $40-50$ & & $16-56$ \\
\hline Surface & 31 & 26 & 40 & 56 & 20 & & $20-56$ \\
\hline Aircraft & 17 & 5 & 10 & 16 & 25 & $31-32$ & $5-32$ \\
\hline Stratosphere & - & 34 & 20 & 5 & 10 & & $5-34$ \\
\hline
\end{tabular}

Table 4: As Table 3 but for July.

Figure 2 showed an increase of measured $\mathrm{NO}_{\mathrm{x}}$ in the upper troposphere over land in summer compared to winter. To attribute this increase to distinct sources we assume that the strength of the lightning, aircraft, and surface $\mathrm{NO}_{\mathrm{x}}$ emissions and the stratosphere flux account for the changes in upper troposphere $\mathrm{NO}_{\mathrm{x}}$. The relative importance $\mathrm{r}^{\mathrm{p}}$ of each $\mathrm{NO}_{\mathrm{x}}$ source $\mathrm{P}$ (lightning, aircraft, surface, and stratosphere $)$ is calculated by $r^{p}=\left[\left(C^{s}-P^{s}\right)-\left(C^{w}-P^{w}\right)\right] /\left\{\sum_{\text {al } P}\left[\left(C^{s}-P^{s}\right)-\left(C^{w}-\right.\right.\right.$ $\left.\mathrm{P}^{\mathrm{w}}\right)$ ] \}, where $\mathrm{C}$ and $\mathrm{P}$ denote the $\mathrm{NO}_{\mathrm{x}}$ mixing ratio at northern upper troposphere mid-latitudes in the control and perturbation simulations, respectively. The indices $s$ and $w$ refer to summer and winter values. At mid-latitude tropopause altitudes the $\mathrm{NO}_{\mathrm{x}}$ to $\mathrm{NO}_{\mathrm{y}}$ ratio decreases in the ECHAM4.L39(DLR)/CHEM model from $25 \%$ to $15 \%$ from $30^{\circ} \mathrm{N}$ to $60^{\circ} \mathrm{N}$ and is around $30 \%$ for the GISS model for both, summer and winter season. So that the ratio remains mainly unchanged between summer and winter. The SONEX and POLINAT2 campaigns showed similar ratios for fall (Singh et al., 1999; Talbot at al., 1999; Ziereis et al., 2000). At mid latitudes and tropopause levels, chemical conversion affects winter and summer values in the same manner and therefore can be neglected for this approach.

Table 5 summarizes the results. All models show that at least $70 \%$ of the increase in summer compared to winter can be attributed to lightning or surface $\mathrm{NO}_{\mathrm{x}}$ emissions. However, some models, including the ECHAM4.L39(DLR)/CHEM and the GISS-model, identify lightning, while others identify surface emissions as the main source for the summer to winter difference. In the ECHAM4.L39(DLR)/CHEM and the GISS-model, the $\mathrm{NO}_{x}$ contributions due to lightning and surface emissions show the same horizontal pattern, reflecting that $\mathrm{NO}_{\mathrm{x}}$ concentrations at tropopause altitudes from both sources are related to convection (not shown). Jeker et al. (2000) analyzed observational data derived during the POLINAT2 and SONEX campaign. They found high $\mathrm{NO}_{\lambda}$ concentrations at the tropopause and could attribute them to lightning events by using backward trajectories and additional satellite data. However, in some cases surface $\mathrm{NO}_{\mathrm{x}}$ still could contribute by a large portion. 


\begin{tabular}{|l|c|c|c|c|c|c|}
\hline & E4C & GISS & Kr96 & Kö97 & Br98 & Total \\
\hline Lightning & 67 & 55 & 27 & 26 & 48 & $26-67$ \\
\hline Surface & 46 & 26 & 49 & 83 & 25 & $25-83$ \\
\hline Aircraft & -23 & 2 & -3 & -17 & 29 & $-17-29$ \\
\hline Stratosphere & $(10)$ & 17 & 27 & 8 & -3 & $-3-27$ \\
\hline
\end{tabular}

Table 5: Contribution [\%] of different $\mathrm{NO}_{x}$ sources to the increase of upper troposphere $\mathrm{NO}_{x}$ in northern mid latitudes from winter to summer. For the ECHAM4.L39(DLR)/CHEM model the same transport characteristic regarding stratospheric $\mathrm{NO}_{x}$ as for the ECHAM3 (Köhler et al., 1997 ) is assumed.

Figure 7 shows the contributions of the different $\mathrm{NO}_{\mathrm{x}}$ sources to the $\mathrm{NO}_{\mathrm{x}}$ and ozone mixing ratio as a function of height. The GISS model shows an aircraft contribution to the atmospheric $\mathrm{NO}_{\mathbf{x}}$ content of $10 \%$ to $20 \%$ in the region from the tropopause to four kilometers below in winter and summer. The contribution due to lightning increases between those heights from around $15 \%$ in winter to $40 \%-50 \%$ in summer, which leads in summer to the local maximum at the tropopause (Figure 3). The importance of surface $\mathrm{NO}_{x}$ emissions decreases with height from $50 \%$ to $10 \%$ in winter and $45 \%$ to $30 \%$ in summer.

\section{Figure 7: Changes in the vertical profile of $\mathrm{NO}_{\mathrm{x}}$ and ozone due to distinct $\mathrm{NO}_{\mathrm{x}}$ sources}

The ECHAM4.L39(DLR)/CHEM model shows a similar behavior regarding the importance of the surface $\mathrm{NO}_{\mathrm{x}}$ sources in the upper troposphere. Maximum impact of surface sources occur 1 to $2 \mathrm{~km}$ below the tropopause in summer (30\% to $40 \%$ ) and $6 \mathrm{~km}$ below the tropopause in winter (80\%). Since ECHAM4.L39(DLR)/CHEM also includes stratospheric chemistry and dynamics, a propagation of upper troposphere $\mathrm{NO}_{\mathrm{x}}$ into the lower stratosphere via the Hadley cell circulation is enabled. This leads to an accumulation of lightning and aircraft $\mathrm{NO}_{x}$ emissions in the lower stratosphere, where the $\mathrm{NO}_{\mathrm{x}}$ lifetime is much longer than in the troposphere due to washout of $\mathrm{HNO}_{3}$. The stratospheric $\mathrm{NO}_{\mathrm{x}}$ can return to the troposphere and increase $\mathrm{NO}_{\mathrm{x}}$ and ozone there, Maximum impacts of lightning and aircraft $\mathrm{NO}_{\mathbf{x}}$ emissions are calculated to be in the lower stratosphere and at tropopause regions, respectively.

The similar shape and magnitude of the impact of surface $\mathrm{NO}_{\mathrm{x}}$ sources also shows that the two different parameterizations for convective mass transport used in either model lead to similar results. Another possibility to evaluate vertical mixing away from the surface are Radon 222 $\left({ }^{222} \mathrm{Rn}\right)$ simulations, since ${ }^{222} \mathrm{Rn}$ is mainly emitted over land and has a short half-life of 3.8 days. The comparison of ${ }^{222} \mathrm{Rn}$ simulations performed with both models (Land, 1999; Rind and Lerner, 1996) show very similar global distributions of ${ }^{222} \mathrm{Rn}$, confirming that ECHAM4.L39(DLR)/CHEM and the GISS model simulate vertical mixing in a similar way. It indicates that the model differences regarding $\mathrm{NO}_{\mathrm{x}}$ mainly arise from the upper boundary condition and lightning parameterization. 
Figure 3 showed a strong summertime increase of measured $\mathrm{NO}_{\mathrm{x}}$ going from the lower stratosphere and upper troposphere to approximately $4 \mathrm{~km}$ below the tropopause. Both models suggest that this increase predominantly results from lightning and surface $\mathrm{NO}_{\mathrm{x}}$ emissions. Their importance varies with altitude. The importance of the lightning emissions increases, whereas the importance of the surface emissions decreases with altitude. At tropopause altitudes it is mainly lightning which causes the $\mathrm{NO}_{\mathrm{x}}$ increase in summer, whereas $4 \mathrm{~km}$ below the tropopause surface emissions are the dominant factor.

Figure 7 (right panel) shows the ozone changes due to various $\mathrm{NO}_{\mathrm{x}}$ sources calculated with the ECHAM4.L39(DLR)/CHEM (top) and the GISS model (bottom). The aircraft induced ozone changes in the lower stratosphere are relatively small compared to the high ozone background. Both models show a several percent change of ozone due to aircraft emissions in the upper troposphere. Surface $\mathrm{NO}_{\mathrm{x}}$ emissions have a si nilar effect on ozone in both models. Their impact is largest in the middle troposphere and decreases with decreasing altitude, i.e. toward the tropopause. However, ECHAM4.L39(DLR)/CHEM shows a larger impact in winter, whereas the GISS model implies this in summer. Since the ECHAM4.L39(DLR)/CHEM model accounts for stratospheric chemistry and since it shows a strong increase of $\mathrm{NO}_{\mathrm{x}}$ in the lower stratosphere due to lightning, therefore the impact of lightning on ozone (15\% to $20 \%$ ) is much stronger than shown by the GISS model ( $5 \%$ to $10 \%$ ).

Figure 8 shows the impact of each $\mathrm{NO}_{\mathrm{x}}$ sources on the frequency distributions of $\mathrm{NO}_{\mathrm{x}}$ and ozone. The ECHAM4.L39(DLR)/CHEM model shows that aircraft emissions not only increase the $\mathrm{NO}_{\mathrm{x}}$ burden in the upper troposphere but also its temporal variability. Aircraft emissions are even the main contributor to the variability in winter. The frequency distribution broadens, and especially $\mathrm{NO}_{x}$ mixing ratios between 40 and 100 pptv occur oftener. The effect of lightning and surface emissions is similar, but not as pronounced. In summer, all sources contribute significantly to the $\mathrm{NO}_{x}$ variability.

Figure 8: Changes in the frequency distribution of $\mathrm{NO}_{x}$ and ozone due to distinct $\mathrm{NO}_{x}$ sources

The GISS model shows reasonable $\mathrm{NO}_{\mathrm{x}}$ frequency distributions. In winter lightning, surface and aircraft $\mathrm{NO}_{\mathrm{x}}$ emissions change the occurrence of low $\mathrm{NO}_{\mathrm{x}}$ values (less than $200 \mathrm{pptv}$ ) only little. Instead, stratosphere-troposphere exchange, namely the upper boundary condition, controls the occurrence of high $\mathrm{NO}_{x}$ values of more than 100 to $150 \mathrm{pptv}$. In summer, the impact of the upper boundary is of much less importance. Instead, lightning contributes significantly to the higher summertime $\mathrm{NO}_{x}$ values, as well as to its variability.

Both models agree that lightning contributes most to the $\mathrm{NO}_{\mathrm{x}}$ variability among all $\mathrm{NO}_{\mathrm{x}}$-sources. However, surface emissions are also of importance in both models and contribute significantly to the variability. The models show very different behavior concerning aircraft emissions. This is related to the treatment of stratospheric transport processes (see discussion above).

The ozone distribution at tropopause levels is strongly determined by stratospheric ozone. The impact of tropospheric $\mathrm{NO}_{x}$ sources is much smaller (see discussion above). Consequently the ozone variability is also hardly affected. Only lightning may change the frequency distribution significantly, as shown by the ECHAM4.L39(DLR) model. In winter, lightning leads to a 
broadening of the ozone frequency distribution, whereas in summer only a shift to higher values is modeled.

\section{CONCLUSIONS AND DISCUSSION}

Aircraft measurements of $\mathrm{NO}_{\mathrm{x}}$ and ozone derived within the Swiss NOXAR project have been extensively compared with two chemistry-climate models. The comparison has been concentrated on the tropopause region on flight routes between Europe and the eastern part of America and between Europe and the Far East. For the first time chemistry models have been intensively validated with regard to upper troposphere mean $\mathrm{NO}_{\mathrm{x}}$ mixing ratios and its variability.

The observations show large longitudinal variations of $\mathrm{NO}_{\mathbf{x}}$. Although the models show regional patterns of $\mathrm{NO}_{x}$ at tropopause altitudes, they do not simulate the strength of the observed longitudinal variations. This clearly indicates a missing $\mathrm{NO}_{\mathrm{x}}$ or $\mathrm{NO}_{\mathrm{y}}$ sink, especially over the North Atlantic. The ECHAM4.L39(DLR)/CHEM model shows too low $\mathrm{NO}_{x}$ mixing ratios with only small longitudinal variations, suggesting that the $\mathrm{NO}_{\mathrm{x}}$, which is released in the upper troposphere is underestimated, and it will be even more underestimated when taking into account an additional $\mathrm{NO}_{x}$ sink. However, sensitivity tests showed a doubling of $\mathrm{NO}_{x}$ mixing ratios, when applying $\mathrm{C}$-shape instead of uniform $\mathrm{NO}_{x}$ emission profiles for flashes, although neither the horizontal distribution nor total amount of the $\mathrm{NO}_{\mathrm{x}}$ lightning emissions was changed.

At $300 \mathrm{hPa}$, i.e. approximately $3 \mathrm{~km}$ below the tropopause, both models are able to simulate strong longitudinal variations indicating that the observed differences are confined to the tropopause altitude.

We examined the reasons for the observed to modeled $\mathrm{NO}_{\mathrm{x}}$ differences and found two possibilities. Either an additional $\mathrm{NO}_{x}$ sink is missing or $\mathrm{HNO}_{3}$ washout is underestimated by either model. For a more detailed examination, budgets of $\mathrm{HO}_{x}, \mathrm{NO}_{x}$ and $\mathrm{NO}_{y}$ are required, including information about cloud water and precipitation, which are not available. The models do not include acetone, which would provide an additional $\mathrm{OH}$ source over remote areas, a potential candidate for a missing $\mathrm{NO}_{\mathrm{x}}$ sink (Arnold et al., 1997). However, Brune et al. (1999) showed that the main sources of $\mathrm{HO}_{x}$ in the northern mid-latitude upper troposphere are water vapor, formaldehyde, and peroxides, with acetone being a smaller contributor. On the other side, there are some indications that $\mathrm{HNO}_{3}$ washout could be underestimated: First results of the Tropical Rainfall Measuring Mission showed larger cloud water amounts due to storms over oceans than over land. The GISS model does not show these differences and simulates cloud water amounts shifted to lower altitudes (Del Genio, personal communication, 2000). If these findings were also be confirmed for the mid-latitudes, it would give reasons that $\mathrm{HNO}_{3}$ washout is underestimated with a distinct land-sea contrast.

The online diagnostics of the GISS model showed distinct differences between chemicaldynamical interactions at $200 \mathrm{hPa}$ and $300 \mathrm{hPa}$. At $200 \mathrm{hPa}$, i.e. tropopause altitudes, $\mathrm{NO}_{\mathrm{x}}$ is mainly controlled by transport, since the chemical net destruction rate is relatively small. The main sinks are meridional and vertical transport, and lightning is the dominant source. At $300 \mathrm{hPa}$, i.e. $3 \mathrm{~km}$ below, $\mathrm{NO}_{\mathrm{x}}$ is controlled by chemistry, with convection as the main source. It indicates again that the transition from the troposphere to the stratosphere is not correctly simulated and that the total $\mathrm{NO}_{\mathrm{x}}$ sink is underestimated at tropopause altitude. 
Although effort has been taken to avoid systematic differences between measurements and model data regarding the sampling method (e.g. comparison relative to tropopause altitude), there are still some possibilities for systematic sampling differences. Model data are taken uniformly over time and space. On the other hand, the aircraft measurements were sampled over various times during day and night, but not uniformly. The aircraft entered the Shannon control area between 6 and 8 UTC and 13 and 17 UTC for east- and westbound flights (Brunner et al., 2000). However, since day and nighttime measurements are included, systematic differences should be small. A more important difference in the sampling of observational and model data may be the fact that the flight routes avoid jet stream areas on west-bound flights, and storm systems entirely. A classification of the $\mathrm{NO}_{\mathrm{x}}$ data with regard to the weather situation and the flight tracks would be necessary. However, the large longitudinal variations are quite unlikely to result solely from sampling differences.

Mean vertical profiles of $\mathrm{NO}_{\mathrm{x}}$ show an E-shape, with maximum values at the surface, below the tropopause, and in the stratosphere, and with minimum values in the free troposphere and lowermost stratosphere. This shape could be reproduced by ECHAM4.L39(DLR)/CHEM model and partially also by the GISS model. However, observed maximum values tend to be some kilometers below the tropopause, whereas the models simulate it directly at the tropopause. Again this is probably related to the simulation of the troposphere-stratosphere transition. It has been shown for the GISS model that the residence time of $\mathrm{NO}_{\mathrm{x}}$ at $200 \mathrm{hPa}$ exceeds those at $300 \mathrm{hPa}$ due to a dramatic change in the chemical sink. It indicates again a missing or underestimated $\mathrm{NO}_{\mathrm{x}}$ sink. Radon 222 experiments yield very similar results for either model (Land, 1999; Rind and Lerner, 1996). Since Radon 222 has a short have-life, this indicates that transport, namely convection and large-scale ascent is simulated similar in either model. It points out that both models show a shift of the $\mathrm{NO}_{\mathrm{x}}$ maximum to higher altitudes for the same reasons.

However, simulated ozone distributions agree well with observations. Even observed sharp vertical gradients at the tropopause were realistically reproduced. This indicates that the horizontal distribution of $\mathrm{NO}_{x}$ and its mean value is of minor importance for the ozone distribution at tropopause levels. Instead the frequency distribution and the most frequent $\mathrm{NO}_{\boldsymbol{x}}$ mixing ratio are of larger importance, since the local net ozone production depends on these values rather than on the mean values. These $\mathrm{NO}_{\mathrm{\lambda}}$ frequency distributions are reasonable simulated by both models with two exceptions. ECHAM4.L39(DLR)/CHEM is missing high $\mathrm{NO}_{\mathrm{x}}$ mixing ratios (greater than $150 \mathrm{pptv}$ in winter and greater than $200 \mathrm{pptv}$ in summer) and the GISS model has too many occurrences of high $\mathrm{NO}_{x}$ mixing ratios in summer. Both models are able to reproduces reasonably the most frequent $\mathrm{NO}_{x}$ mixing ratios.

The ECHAM4.L39(DLR)/CHEM model was run in to modes, with and without interactively coupling of the chemistry with dynamics. Both model versions showed similar results, justifying the use of the off-line version for sensitivity tests.

The ECHAM4.L39(DLR)/CHEM model (off-line version) and the GISS model were used to estimate the impact of individual $\mathrm{NO}_{x}$ sources on the $\mathrm{NO}_{x}$ and ozone distribution. They showed that the seasonal changes in $\mathrm{NO}_{\mathrm{x}}$ are mainly due to lightning $\mathrm{NO}_{\mathrm{x}}$ emissions. The impact of lightning emissions on the $\mathrm{NO}_{x}$ and ozone distribution in the upper troposphere is mostly constant or slightly increasing with altitude, whereas the impact of surface emissions strongly decreases. Lightning also contributes most to the $\mathrm{NO}_{\mathrm{x}}$ variability in summer. In winter, aircraft emissions contribute most to the $\mathrm{NO}_{x}$ variability in the ECHAM4.L39(DLR)/CHEM model, whereas stratosphere to troposphere exchange is the dominant contributor in the GISS model. 
Although there are several qualitative agreements between the models, also discrepancies occur: Due to the different treatment of the chemistry and dynamics in the lowermost stratosphere, the effect of aircraft and lightning emissions on the $\mathrm{NO}_{x}$ distribution and the effect of lightning $\mathrm{NO}_{x}$ emissions on the ozone distribution differs significantly. ECHAM4.L39(DLR)/CHEM shows a much larger impact of aircraft emissions on the $\mathrm{NO}_{x}$ distribution at the tropopause especially in winter and a much larger effect on ozone due to lightning.

The horizontal patterns of the upper troposphere $\mathrm{NO}_{\mathrm{x}}$ distribution clearly mirrors the emissions, i.e. maximums over industrial regions and regions with high convective activity. This indicates that the ratio of the chemical $\mathrm{NO}_{x}$ lifetime to the dynamical lifetime is small enough to allow for regional patterns. However, the comparison to observations shows clearly that the chemical $\mathrm{NO}_{\mathrm{x}}$ lifetime is overestimated at tropopause altitudes. The estimated importance of individual $\mathrm{NO}_{x}$ sources should not be affected thereby, since emphasis is giv sn to relative changes.

Acknowledgements - This work was supported by the NASA Atmosphere and Chemistry Modeling and Analysis Program and by the project AEROCHEM2 of the European Union. We like to thank David Rind, NASA-GISS, for helpful discussions.

\section{REFERENCES}

Arnold F., Burger V., Droste-Fanke B., Grimm F., Krieger A., Schneider J., Stilp T. (1997) Acetone in the upper troposphere and lower stratosphere: impact on trace gases and aerosols, Geophysical Research Letters 24, 3017-3020.

Benkovitz, C.M., Scholtz, M.T., Pacyna, J., Tarrason, L., Dignon, J., Voldner, E.C., Spiro, P.A., Logan, J.A. and Graedel, T.E. (1996) Global gridded inventories of anthropogenic emissions of sulfur and nitrogen, Journal of Geophysical Research 101, 29,239-29,253.

Brasseur, G.P., Cox, R.A., Hauglustaine, D., Isaksen, I., Lelieveld, J., Lister, D.H., Sausen, R., Schumann, U., Wahhner, A. and Wiesen P. (1998) European scientific assessment of the atmospheric effects of aircraft emissions, Atmospheric Environment 32, 2329-2418.

Brune, W.H., Tan, D., Faloona, I.F., Jaeglé, L., Jacob, D.J., Heikes, B.G., Snow, J., Kondo, Y., Shetter, R., Sachse, G.W., Anderson, B., Gregory, G.L., Vay, S., Singh, H.B., Davis, D.D.,Crawford, J.H., and Blake, D.R. (1999) $\mathrm{OH}$ and $\mathrm{HO}_{2}$ chemistry in the North Atlantic free troposphere, Geophysical Research Letters 26, 3077-3080.

Brunner, D. (1998) One-year climatology of nitrogen oxides and ozone in the tropopause region - Results from B-747 aircraft measurements, Ph.D. Thesis, 181 pp., Swiss Federal Institute of Technology (ETH), Zürich, Switzerland.

Brunner, D., Staehelin, J., Jeker, D. (1998) Large-scale nitrogen oxide plumes in the tropopause region and implications for ozone, Science 282, 1305-1309.

Brunner, D., Staehelin, J., Jeker, D., Wernli, H., and Schumann U. (2000) Nitrogen oxides and ozone in the tropopause region - one year of in-situ measurements during the project NOXAR, in preparation.

Christian, H.J., Driscoll, K.T., Goodman, S.J., Blakeslee, R.J., Mach, D.A. and Buechler, D.E. (1996) The Optical Transient Detector (OTD), Proceedings of the 10th International Conference on Atmospheric Electricity; Osaka, Japan; June 10-14, 368-371. 
Del Genio, A.D., Yao,, M.-S. (1992) Efficient cumulus parameterization for long-term climate studies: the GISS scheme, in Cumulus Parameterization, AMS Monogr. Ser., ed. K. Emanuel, D. Raymond, American Meterological Society, Boston, Mass.

Del Genio, A.D., Yao, M.S., Kovari, W., and Lo, K.K.W. (1996) A prognostic cloud water parameterization for global climate models, Journal of Climate 9, 270 -304.

DeMore, W.B., Sander, S.P., Howard, C.J., Ravishankara, A.R., Golden, D.M., Kolb, C.E., Hampson, R.F., Molina, M.J. and Kurylo, M.J. (1997) Chemical kinetics and photochemical data for use in stratospheric modeling, J.P.L. Publication 97-4.

Dentener, F.J., and Crutzen, P.J. (1993) Reaction of $\mathrm{N}_{2} \mathrm{O}_{5}$ on tropospheric aerosols: Impact on the global distributions of $\mathrm{NO}_{x}, \mathrm{O}_{3}$, and $\mathrm{OH}$, Journal of Geophysical Research 98, 7149-7163.

Dias-Lilcaca, P., Brunner, D., Imfeld, W., Moser, W. and Staehelin, J. (1998) An automated system for the measurement of nitrogen oxides and ozone concentrations from a passenger aircraft - instrumentation and first results of the NOXAR project, Environmental Science \& Technology 32, 3228-3236.

Emmons, L.K., Carroll, M.A., Hauglustaine, D.A., Brasseur, G.P., Atherton, C., Penner, J., Sillman, S., Levy II., H., Rohrer, F., Wauben, W.M.F., van Velthoven, P.F.J., Wang, Y., Jacob, D., Bakwin, P., Dickerson, R., Doddridge, B., Gerbig, C., Honrath, R., Hübler, G., Jaffe, Kondo, D.,Y., Munger, J.W., Torres, A., Volz-Thomas, A. (1997) Climatologies of $\mathrm{NO}_{x}$ and $\mathrm{NO}_{y}$ Comparison of data and models, Atmospheric Environment 31, 1851-1904.

Fishman, J. and Crutzen, P.J. (1979) The origin of ozone in the troposphere, Nature 274, 853858.

Fishman, J., Ramanathan, V., Crutzen, P.J. and Liu, S.C. (1979) Tropospheric ozone and climate, Nature 282, 818-820.

Gates, W.L. (1992) The atmosphere model intercomparison, Bulletin of the American Meteorological Society 73, 1962-1970.

Gordon, H.R., and Wang, M. (1994) Influence of oceanic whitecaps on oceanic correction of SeaWiFS, Applied Optics 33, 7754-7763.

Grewe, V. and Dameris, M. (1996) Calculating the global mass exchange between stratosphere and troposphere, Annales Geophysicae 14, 431-442.

Hansen, J., Russell, G., Rind, D., Stone, P., Lacis, A., Lebedeff, S., Ruedy, R., and Travis, L. (1983) Efficient three-dimensional global models for climate studies: models I and II, Monthly Weather Review 111, 609-662.

Hansen, J., Sato, M., Ruedy, R., Lacis, A., Asamoah, K., Beckford, K., Borenstein, S., Brown, E., Cairns, B., Carlson, B., et al. (1997a) Forcings and chaos in interannual to decadal climate change, Journal of Geophysical Research 102, 25,679-25,720.

Hansen, J., Sato, M., and Ruedy, R. (1997b) Radiative forcing and climate response, Joumal of Geophysical Research 102, 6831-6864.

Hao, W.M., Liu, M.-H. and Crutzen, P.J. (1990) Estimates of annual and regional releases of $\mathrm{CO}_{2}$ and other trace gases to the atmosphere from fires in the tropics, based on the FAO statistics for the period 1975-1980, In Fire in the Tropical Biota, Ecological Studies 84, (ed. J.G. Goldammer), 440-462, Springer-Verlag, New York, USA. 
Hartke, G.J., and Rind, D. (1997) Improved surface and boundary layer models for the GISS general circulation model, Journal of Geophysical Research 102, 16,407-16,422.

Hein R., Dameris, M., Grewe, V., Schnadt, C., Steil, B., and Landgraf, J., (2000) Results of an interactively coupled atmospheric chemistry - general circulation model: Comparison with observations, submitted to Journal of Geophysical Research.

IPCC - Intergovernmental Panel on Climate Change (1996) Climate change 1995, eds. J.T. Houghton, L.G. Meira Filho, B.A. Callander, N. Harris, A. Kattenberg, and K. Maskell, Cambridge University Press, New York, USA.

IPCC - Intergovernmental Panel on Climate Change (1999) Aviation and the global atmosphere, eds. J.E. Penner, D.H. Lister, D.J. Griggs, D.J. Dokken, M. McFarland, pp. 373, Cambridge University Press, Cambridge, UK.

Jeker, D.P., Pfister, L., Thompson, A.M., Brunner, D., Pickering, K.E., Boccippio, D.J., Wernli, H., Kondo, Y., Staehelin, J. (2000) Measurements of nitrogen oxides at the tropopause attribution to convection and correlation with lightning, Joumal of Geophysical Research, in press.

Koch, D., Jacob, D., Tegen, I., Rind, D., and Chin, M. (1999) Tropospheric sulfur simulation and sulfate direct radiative forcing in the GISS GCM, Journal of Geophysical Research 104, $23,799-23,822$.

Köhler, I., Sausen, R. and Reinberger, R. (1997) On the contribution of aircraft emission to the atmospheric $\mathrm{NO}_{\mathrm{x}}$ content, Atmospheric Environment 31, 1801-1818.

Krauss, A.B., Rohrer, F., Grobler, E.S. and Ehalt D.H. (1996) The global tropospheric distribution of $\mathrm{NO}_{\mathrm{x}}$ estimated by a three-dimensional chemical tracer model, Journal of Geophysical Research 101, 18,587-18,604.

Land, C. (1999) Untersuchungen zum globalen Spurenstofftransport mit dem Atmosphärenmodell ECHAM4.L39(DLR), Ph.D. Thesis, Fakultät für Physik, LudwigMaximilians-Universität München, Germany.

Land, C., Ponater, M., Sausen, R. and Roeckner, E. (1999) The ECHAM4.L39(DLR) Atmosphere General Circulation Model, manuscript in preparation, 1999.

Lelieveld, J. and Thompson, A.M. (1999) Tropospheric ozone and related processes, In Scientific assessment of ozone depletion: 1998, WMO-Report 44, 8.1-8.42.

Olson, J., Prather, M., Bernsten, T., Carmicheal, G., Chatfield, R., Connell, P., Derwent, R., Horowitz, L., Shengxin, J., Kanakidou, M., Kasibhatla, P., Kotamarthi, R., Kuhn, M., Law, K., Penner, J., Perliski, L., Sillman, S., Stordal, F., Thompson, A., and Wild, O. (1997) Results from the intergovernmental panel on climate change photochemical model intercomparison (photocomp), Joumal of Geophysical Research 102, 5979-5991.

Pickering, K.E., Yansen, W., Wei-Kuo, T., Price, C. and Muller, J.-F. (1998) Vertical distributions of lightning $\mathrm{NO}_{\mathrm{x}}$ for use in regional and global chemical transport models. Journal of Geophysical Research 103, 31,203-31,216.

Ponater, M., Sausen, R., Feneberg, B., Roeckner, E (1999) Climate effect of ozone changes caused by present and future air traffic, Climate Dynamics 15, 631-642.

Price, C. and Rind, D. (1994) Modeling global lightning distributions in a general circulation model, Monthly Weather Review 122, 1930-1937. 
Price, C., Penner, J., and Prather, M. (1997) $\mathrm{NO}_{\mathrm{x}}$ from lightning. 1. Global distribution based on lightning physics, Journal of Geophysical Research 102, 5929-5941.

Rind, D., and Lerner, J. (1996) The use of on-line tracers as a diagnostic tool in GCM model development, Journal of Geophysical Research 101, 12,667-12,683.

Roeckner, E., Arpe, K., Bengtsson, L., Christoph, M., Claussen, M., Dümenil, L., Esch, M., Giorgetta, M., Schlese, U., and Schulzweida, U. (1996) The atmospheric general circulation model ECHAM4: Model description and simulation of present-day climate, MPI-Report 218, ISSN 0937-1060, Max-Planck-Institut für Meteorologie, Hamburg, Germany,

Rosenzweig, C., and Abramopoulos, F. (1997) Land surface model development for the GISS GCM, Journal of Climate 10, 2040-2054.

Rossow, W.B., and Zhang, Y.C. (1995) Calculation of the top-of-the-atmosphere radiative fluxes from physical quantities derived from ISCCP data sets, II, Validation arid results, Journal of Geophysical Research 100, 1167-1197.

Shindell, D.T., Grenfell, J.L., Rind, D., Price, P., and Grewe, V. (2000) Chemistry-climate interactions in the GISS GCM. 1: Tropospheric chemistry model description and evaluation, to be submitted to Journal of Geophysical Research.

Schmitt, A. and Brunner, B. (1998) Emissions from aviation and their development over time, In Pollutants from air traffic - results of atmospheric research 1992-1997, DLR-Mitt. 97-04, (eds. U. Schumann et al.), 37-52, DLR Köln, Germany.

Singh, H.B., Thompson, A.M., and Schlager, H. (1999) SONEX airborne mission and coordinated POLINAT-2 activity: overview and accomplishments, Geophysical Research Letters 26, 3053-3056.

Steil, B., Dameris, M., Brühl, C., Crutzen, P.J., Grewe,V., Ponater, M. and Sausen, R., (1998) Development for a chemistry module for GCMs: First results of a multi-annual integration, Annales Geophysicae 16, 205-228.

Talbot, R.W., Dibb, J.E., Scheuer, E.M., Kondo, Y., Koike, M., Singh, H.B., Salas, L.B., Fukui, Y., Ballenthin, J.O., Meads, R.F., Miller, T.M., Hunton, D.E., Viggiano, A.A., Blake, D.R., Blake, N.J., Atlas, E., Flocke, F., Jacob, D.J., and Jaegle, L. (1999) Reactive nitrogen budget during NASA SONEX mission, Geophysical Research Letters 26, 3057-3060.

Wang, W.-C. and Sze, N.D. (1980) Coupled effects of atmospheric $\mathrm{N}_{2} \mathrm{O}$ and $\mathrm{O}_{3}$ on the Earth's climate, Nature 286, 589-590.

Wang, Y., Jacob, D.J., and Logan, J.A. (1998) Global simulation of tropospheric $\mathrm{O}_{3}-\mathrm{NO}_{\mathrm{x}}$ hydrocarbon chemistry. 1. Model formulation, Journal of Geophysical Research 103, 10,71310,725 .

WMO - World Meteorological Organization (1999) Scientific assessment of the ozone depletion: 1998, Report No. 44, Geneva, Switzerland.

Yienger, J.J. and Levy II, H. (1995) Empirical model of global soil-biogenic NO emissions, Journal of Geophysical Research 100, 11,447-11,464.

Ziereis, H., Schlager, H., Schulte, P., van Velthoven, P.F.J., Slemr, F. (2000) Distributions of $\mathrm{NO}, \mathrm{NO}_{\mathrm{x}}$, and $\mathrm{NO}_{\mathrm{y}}$ in the upper troposphere and lower stratosphere between $28^{\circ} \mathrm{N}$ and $61^{\circ} \mathrm{N}$ during POLINAT2, Journal of Geophysical Research, in press. 


\section{Figures}

Figure 1: Area covered by NOXAR measurements. Thin lines indicate the land-sea mask in T30 resolution, as used by the ECHAM4.L39(DLR)/CHEM model.

Figure 2: Seasonal $\mathrm{NO}_{\mathrm{x}}$ volume mixing ratios (pptv) in the tropopause region $( \pm 25 \mathrm{hPa}$ relative to the local tropopause) and as a mean of all latitudes covered by the NOXAR measurements. The very heavy solid, heavy solid, the solid and the dotted lines represent NOXAR measurements, the online version, the offline version of ECHAM4.L39(DLR)/CHEM model, and the GISS-model, respectively. The inter-annual standard variation is added for the models. The number of NOXAR measurements per grid box (i.e. per $3.75^{\circ}$ ) is added.

Figure 3: Mean vertical $\mathrm{NO}_{x}$ profiles (pptv) relative to the tropopause for each season. The very heavy solid, heavy solid, the solid and the dotted lines represent NOXAR measurements, the online version, the offline version of ECHAM4.L39(DLR)/CHEM model, and the GISSmodel, respectively. The inter-annual standard variation is added for the models. The number of NOXAR measurements per grid box (i.e. per $\mathrm{km}$ ) is added. The high spring at 2 to $4 \mathrm{~km}$ below the tropopause are cause by individual large plumes, and may not represent the climatological mean value.

Figure 4: $\mathrm{NO}_{\mathrm{x}}$ Budgets for the GISS model for the $7^{\text {th }}(200 \mathrm{hPa})$ and $6^{\text {th }}(300 \mathrm{hPa})$ level in the latitude range $40^{\circ} \mathrm{N}$ to $60^{\circ} \mathrm{N}$ for January (italic) and July (bold). $\mathrm{NO}$ exchange due to horizontal and vertical transport, convection, chemical processes, lightning and aircraft emissions are given in $\mathrm{kg} \mathrm{s}^{-1}$. Total $\mathrm{NO}_{\mathrm{x}}$ mass is given in $10^{5} \mathrm{~kg}$.

Figure 5: As Figure 3, but for ozone (ppbv).

Figure 6: Frequency distributions for (left) and ozone (right) derived from NOXAR measurements (top), ECHAM4.L39(DLR)/CHEM data (middle) and GISS data (bottom). Model data represent 12 hourly means.

Figure 7: Contributions [in \% of the cortrol simulation] of aircraft (red), lightning (green) and surface (yellow) $\mathrm{NO}_{\mathrm{x}}$ emissions as well as the upper boundary (blue) upper troposphere and lower stratosphere $\mathrm{NO}_{x}$ (right) and ozone (left) concentration derived with the ECHAM4.L39(DLR)/CHEM (top) and GISS-model (bottom). Values are given for DJF (solid) and JJA (dotted). For the GISS model values above the tropopause are defined by the upper boundary and therefore either $0 \%$ or $100 \%$, indicated with thinner lines.

Figure 8: Frequency distributions for $\mathrm{NO}_{x}$ (top) and ozone (bottom) derived with the ECHAM4.L39(DLR)/CHEM and GISS-model for the control runs (solid) and perturbation runs without lightning (long dashed), aircraft (short dashed), surface emissions (dotted) and without a stratospheric flux (dotted-dashed). 


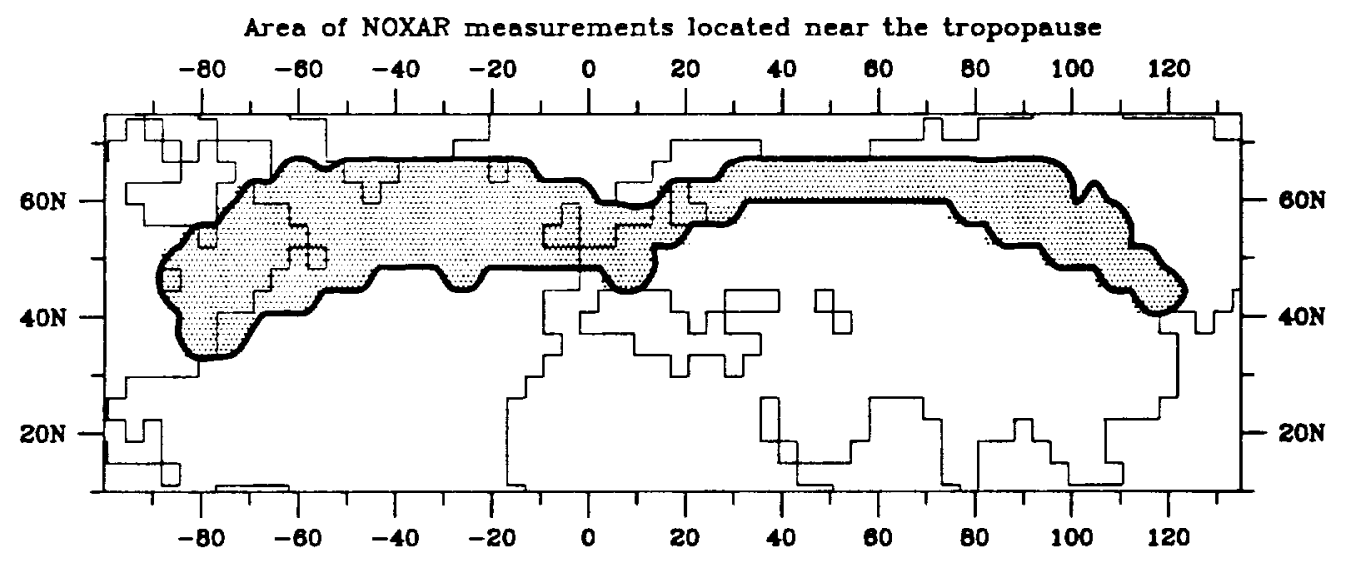



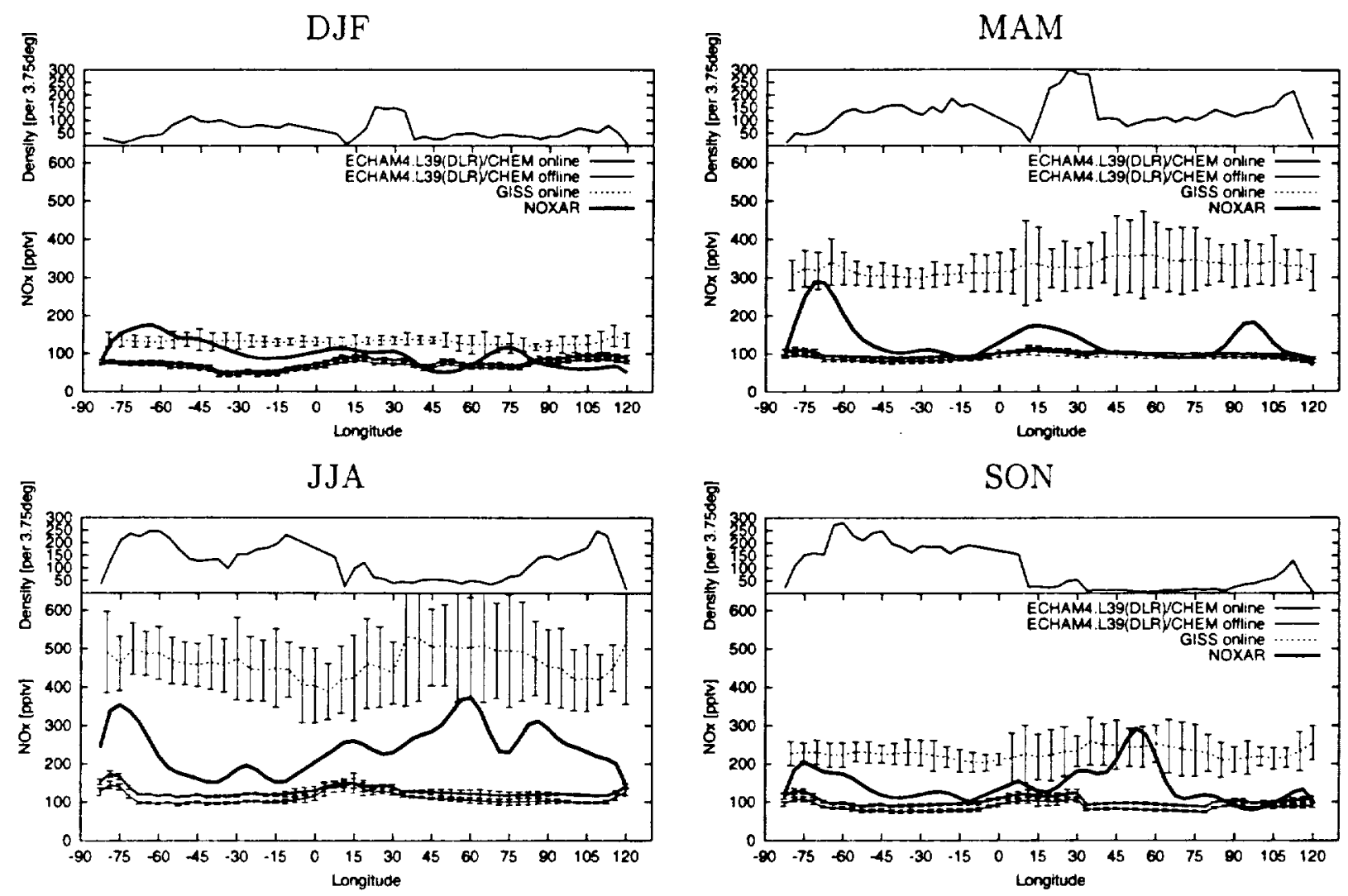

Figure 2 


\section{DJF}

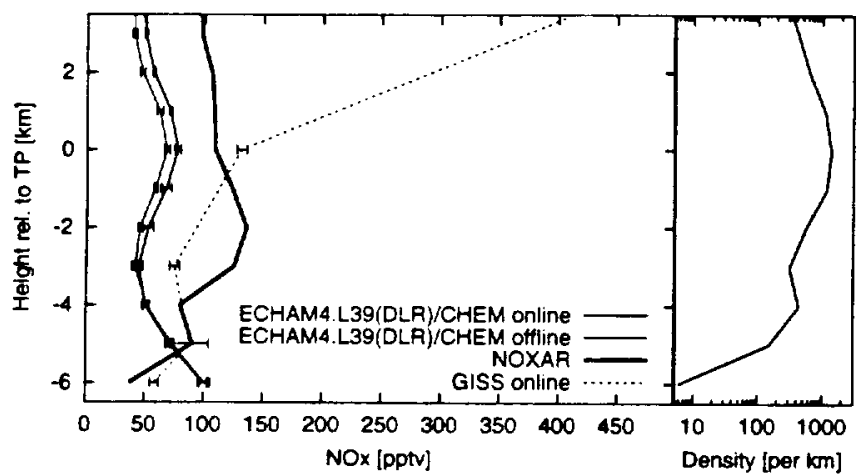

JJA

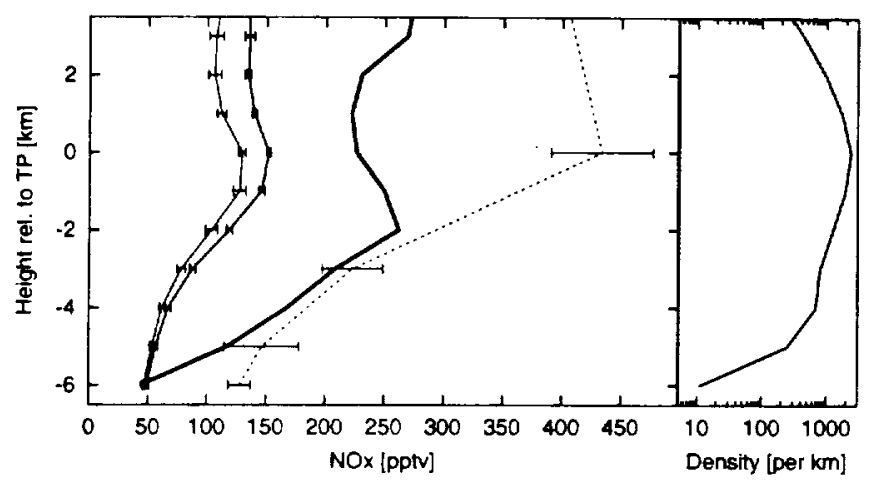

MAM

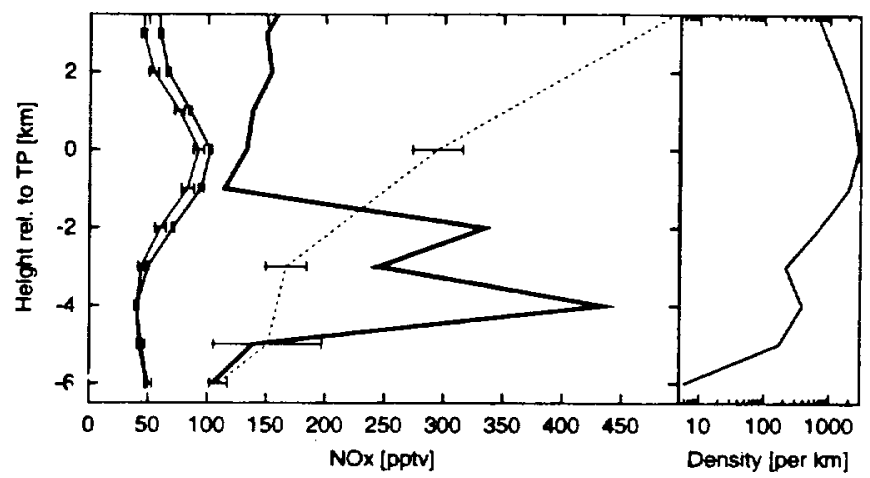

SON

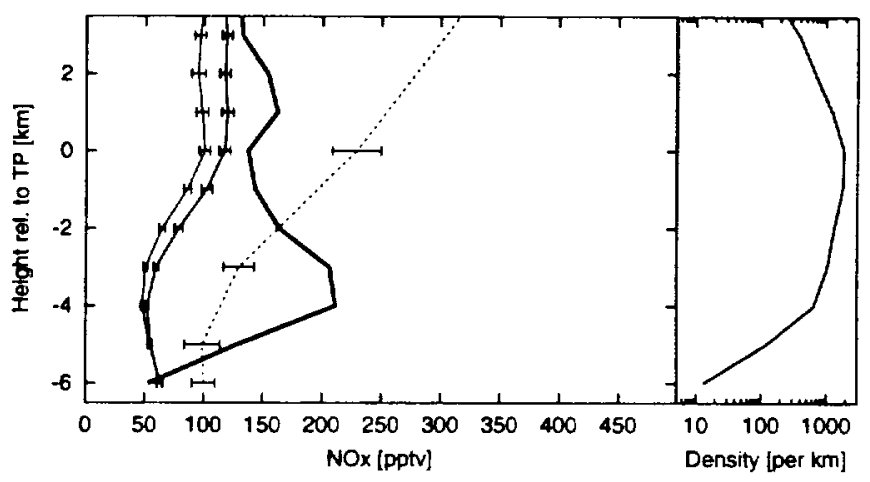

Figure 3 

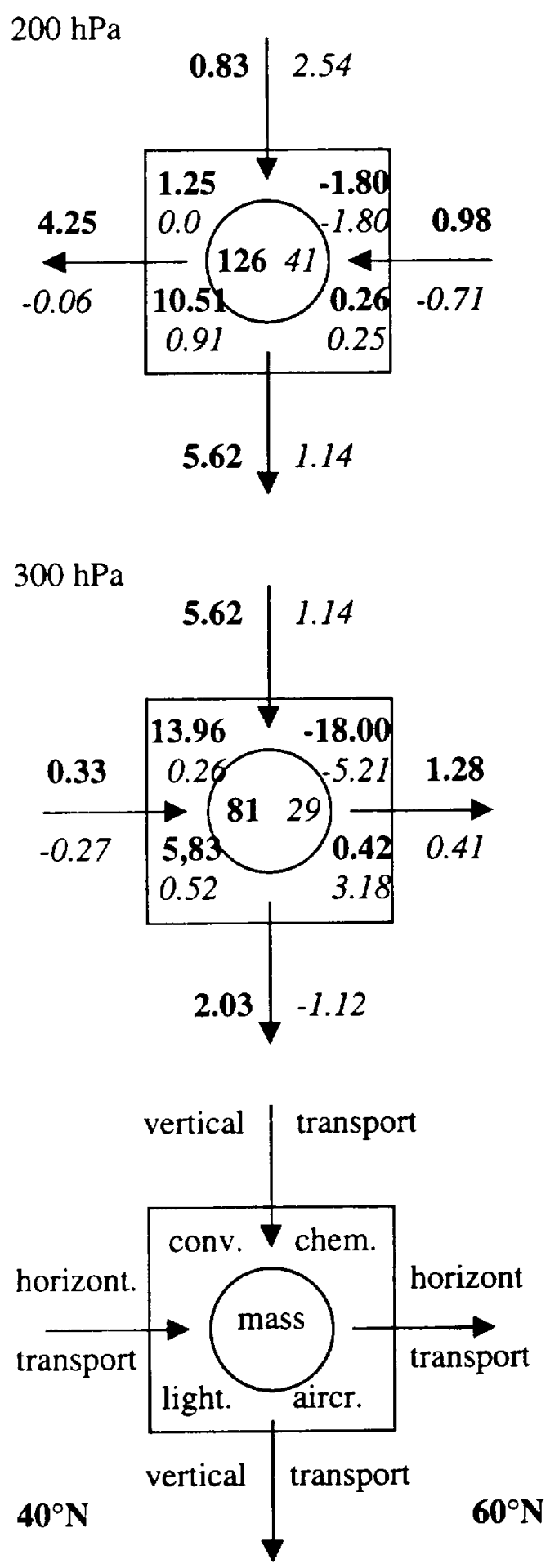

Figure 4 
DJF

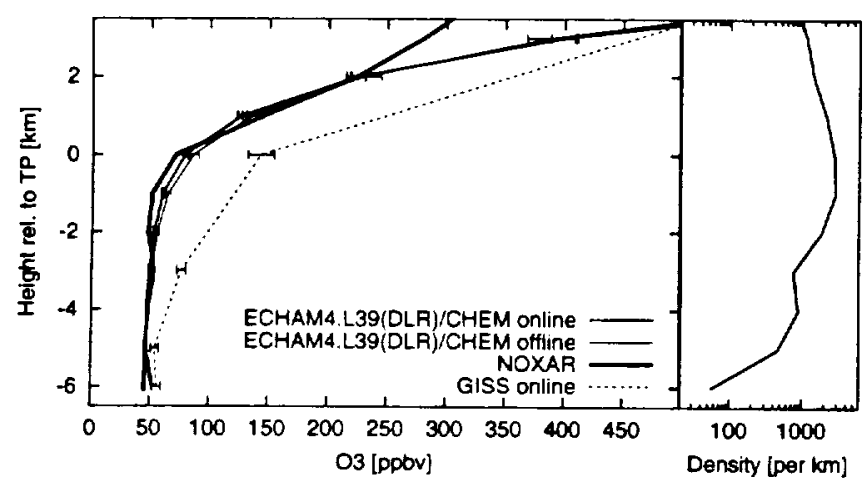

JJA

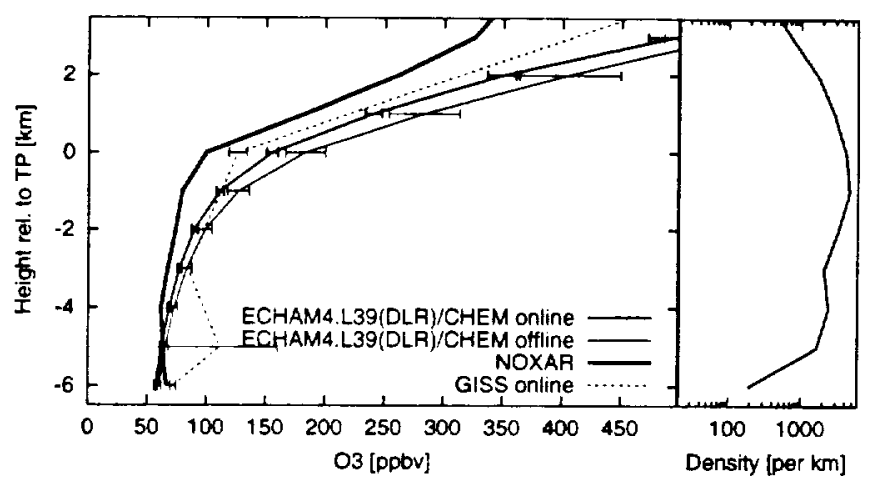

MAM

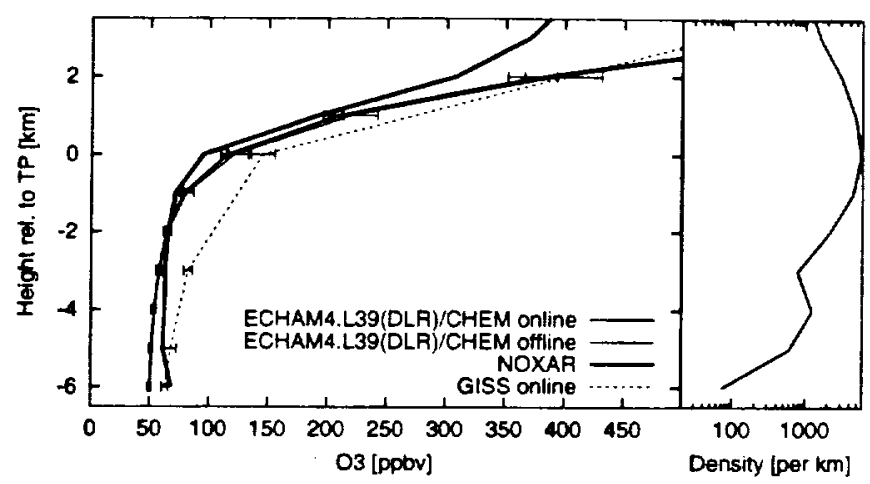

SON

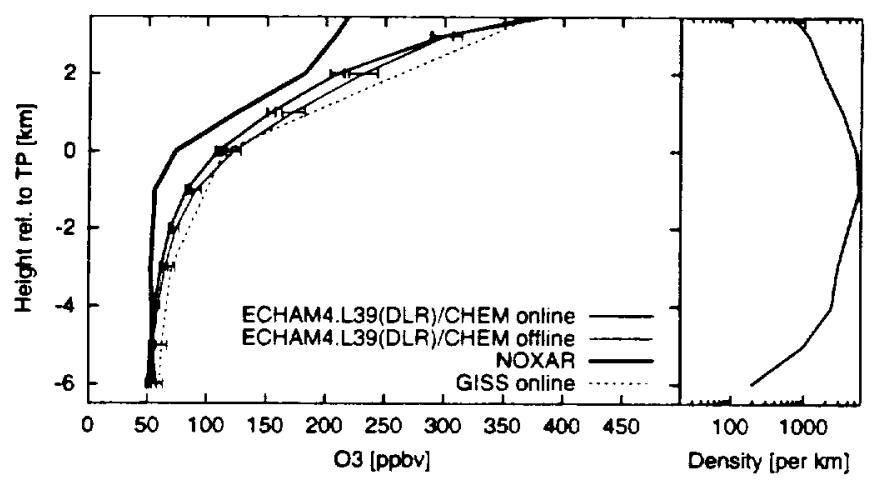

\section{Figure 5}



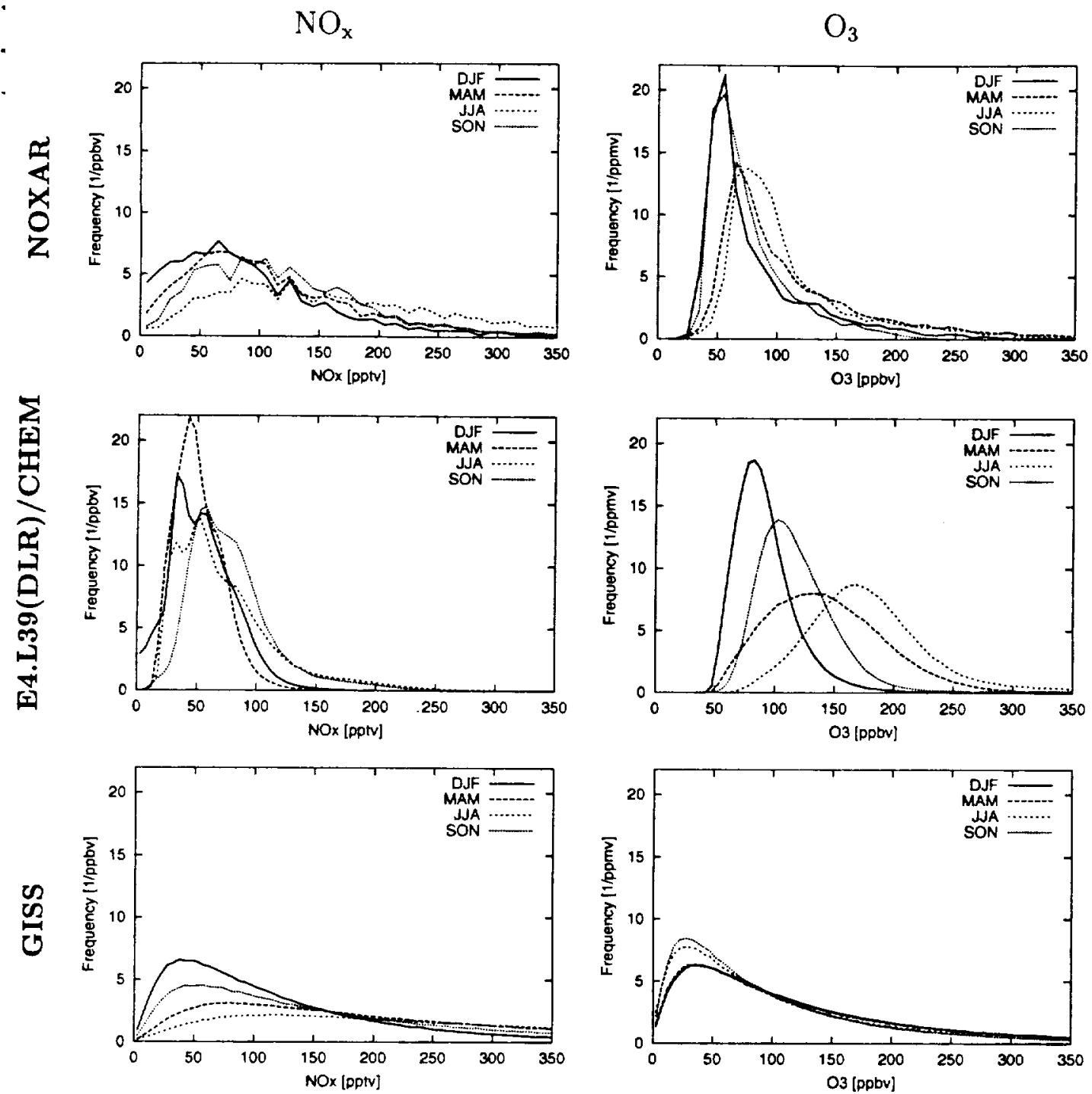

Figure 6 

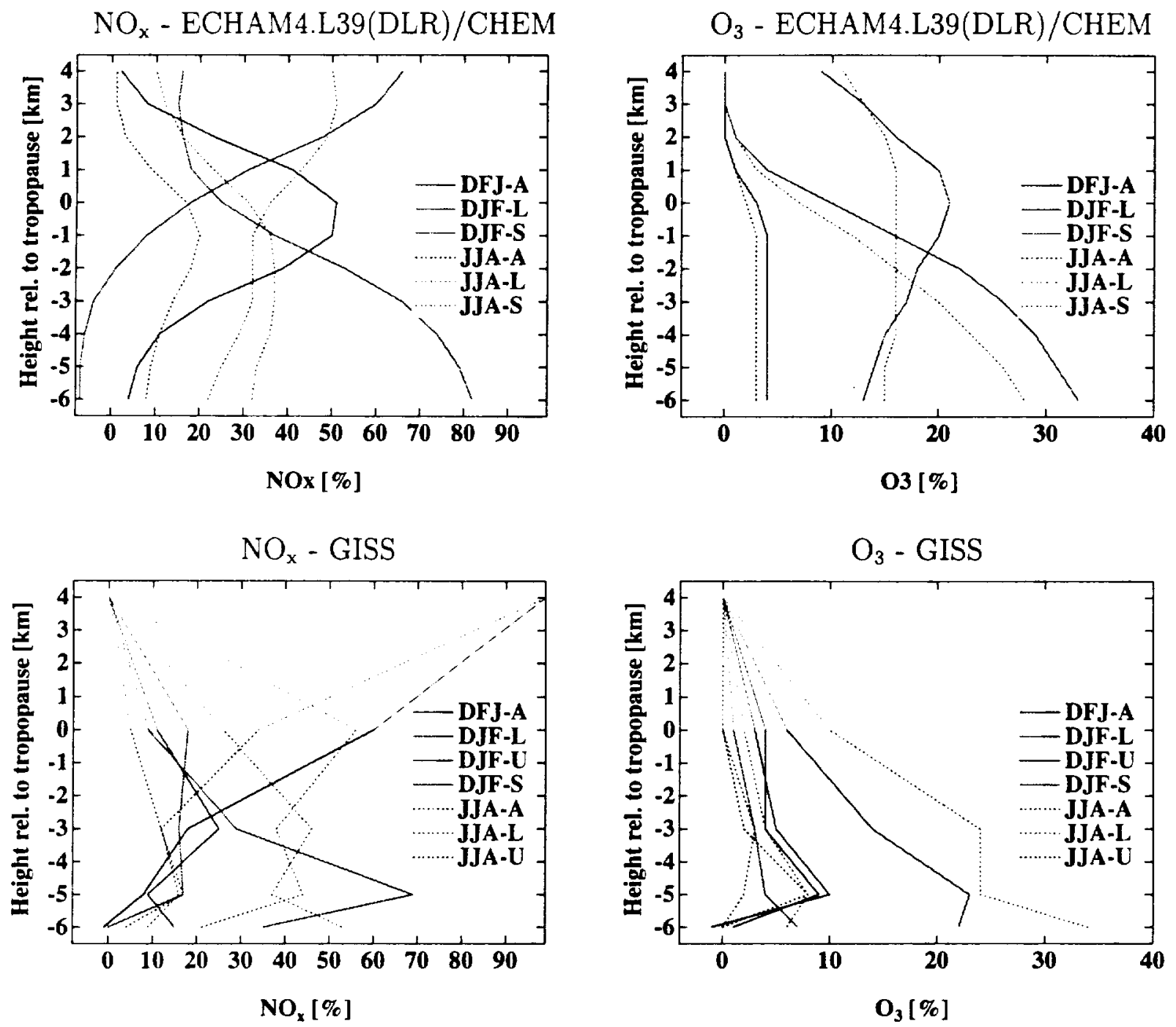

Figure 7 
DJF

$\mathrm{NO}_{\mathbf{x}}$
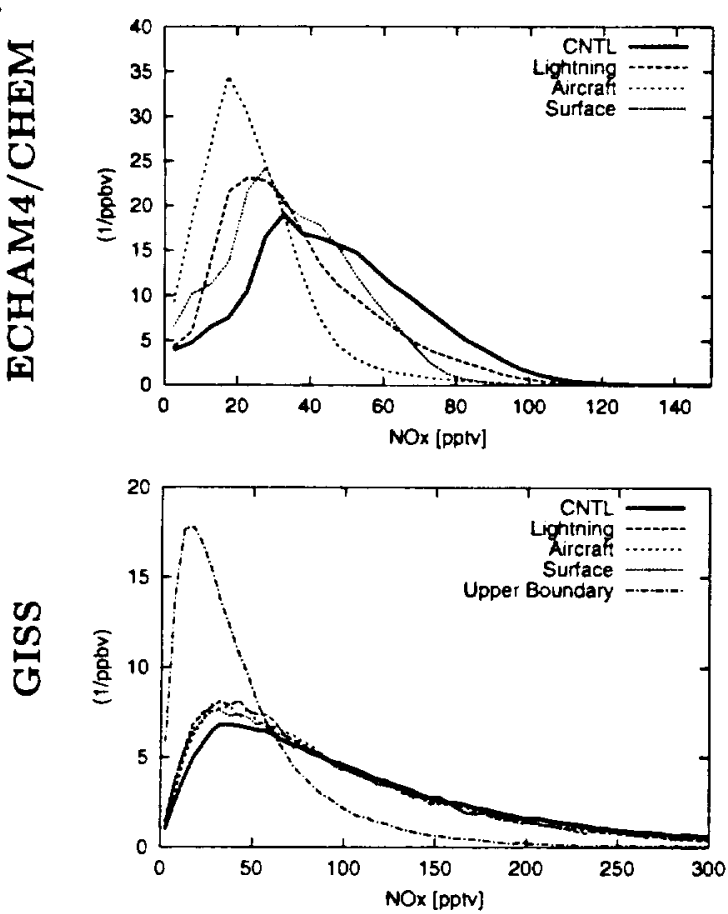

$\mathrm{O}_{3}$

DJF
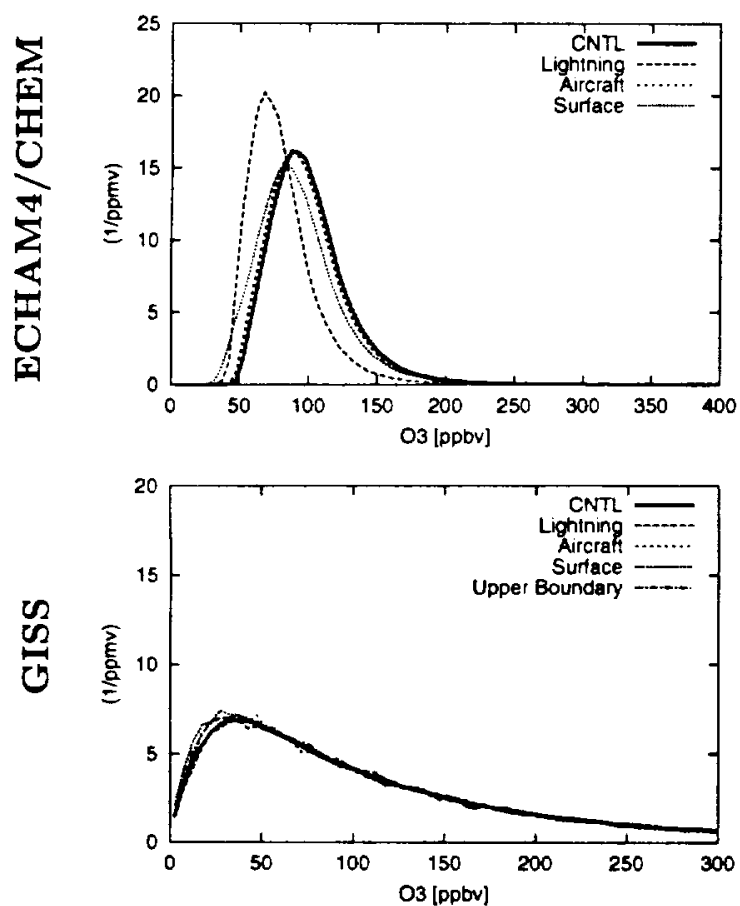

Figure 8
JJA
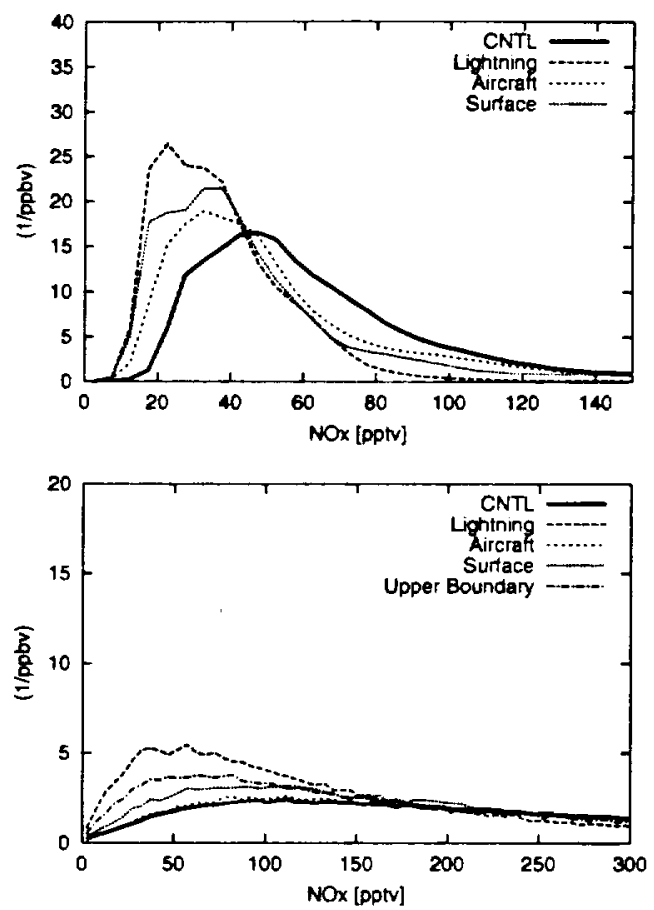

JJA
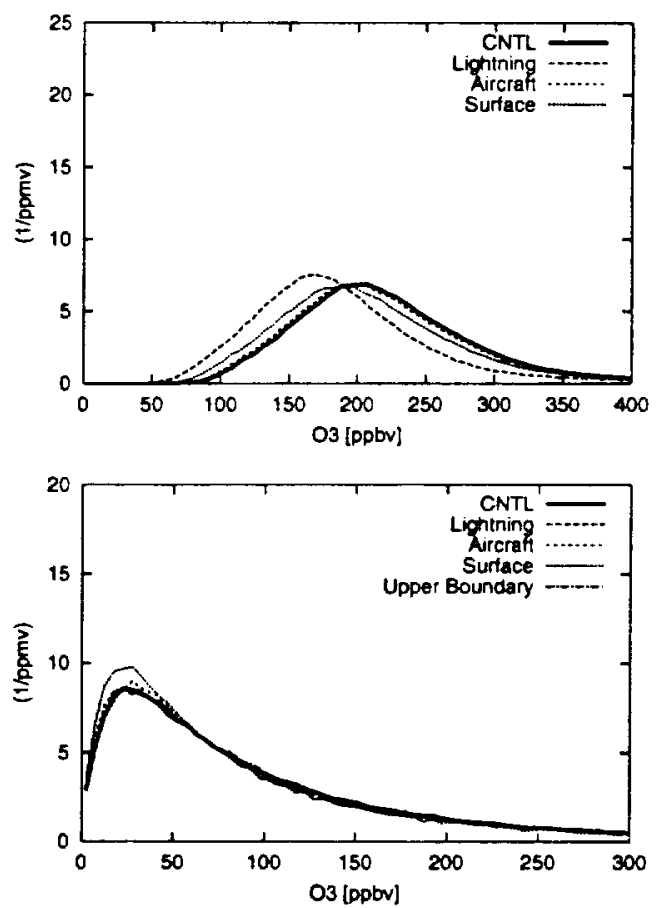